\title{
After at Least 138 Years of Discussion, the Etymological Puzzle is Possibly Solved: The Originally British English informalism kibosh as in "put the kibosh on [something]" could Come from the Clogmakers' Term kybosh 'iron bar which, when hot, is used to soften and smooth leather' (with Possible Reinforcement from Western Ashkenazic British English khay bash 'eighteen pence')
}

\author{
David L. Gold \\ New York
}

\begin{abstract}
The sources suggested for the originally British and variously spelled English slang idiom put the kibosh on [...] are so diverse - ranging, for example, from Irish and Scots Gaelic to Yiddish and Hebrew, not to mention English that no one person could possess enough knowledge to evaluate all of them competently and to answer all the questions that must be answered before we could say "case closed". For that reason, the author of the present article treads here, as his wont is, only where he feels sure of foot.
\end{abstract}

Philologists who chase

A panting syllable through time and space,

Start it at home, and hunt it in the dark,

To Gaul, to Greece, and into Noah's Ark

(William Cowper, Retirement, 1782)

The real work of critical inquiry is to examine what we think we know in order to learn about what we do not know. We must question our givens and opinions. For it is far easier to label than to understand, and intellectual laziness undermines our studies with the deadly inversion of the scientific method: 'I'll believe it when I see it!' becomes 'I'll see it when I believe it!'

(Homerin 2003: 6) 


\section{Introduction}

When Samuel Johnson was taken to task for criticizing William Shakespeare, he said, "We must confess the faults of our favourite, to gain credit to our praise of his excellencies. $\mathrm{He}$ that claims, either in himself or for another, the honours of perfection, will surely injure the reputation which he designs to assist" (letter to Charles Burney, 16 October 1765).

Paraphrasing the Rambler, I say, "I must with alacrity acknowledge that this or that English usage is not of any Jewish origin, to gain credit to any English etymology of mine which does involve a Jewish language [actually, only respect for the truth motivates my acknowledgments]. He that repeatedly claims a Jewish origin unjustifiedly, will surely be looked at askance even when he is right".

In essence, then, neither do I want to be the boy who cries "Wolf!" if there is no wolf (to my credit stand chapters 4, 5, 7, 9, 14, 15, 16, 20, 25, and 31 in Gold 2009a, as well as certain earlier publications, such as Gold 1989b, 1990b, and 1995, each of which disproves or questions a proposed or an "established" etymology according to which a certain item in a non-Jewish language, say, English or French, derives from a Jewish language, say, Yiddish or Hebrew) nor do I want to be the boy who fails to cry "Wolf!" if it does come, my only goal being to discover the truth and relate it accurately.

Under discussion here will be the originally British, later also Australian, and still later also American and Canadian English slangism cibosh $\sim$ kaibosh $\sim$ kibbosh $\sim$ kibosh kybosh $\sim$ kye-bosh $\sim$ kye-bosk, which occurs most often in the slang verb phrase put the cibosh kaibosh kibbosh kibosh kybosh kye-bosh kye-bosk on [...] 'can [...], check [..], dispose of [...] finally, do for [...], put an end to [...], put paid to [...], quash [...], render [...] definitely impossible, render [...] definitely out of the question, squelch [...], stifle [...], veto [...]' (as in "Another such injury may put the kibosh on her athletic career" and "As soon as the manager found out about the assistant manager's risky plan, she put the kibosh on it"). In that idiom, then, the noun means 1. 'check, restraint' 2. 'veto'. Since the word has other meanings too (for example, 'Portland cement'), we do not yet know whether we are dealing with (1) a single word (which by definition can have just one etymology) that has more than one meaning or (2) more than one word (each of which by definition has just one etymology), each of which has at least one meaning.

Confronting us here is thus a question which etymologists and lexicologists in most of the world's languages face from time to time: polysemy or homonymy? ${ }^{1}$ Whatever the answer to it may be in the present instance, hereinafter we will for brevity's sake refer to "our problematic word" rather than, as we should, to "our problematic word or words".

Step by step, we will sort out from our problematic word (1) the (originally Western) Ashkenazic British English free collocation khay bash 'eighteen pence', which is of immediate Western Yiddish origin, (2) the British English underworld (including prison) slangism kaybash 'sentence of eighteen months in prison', which is of non-immediate Western Yiddish origin, (3) the clogmakers' term kibosh 'iron bar which, when hot, is used to soften and smooth leather', which consists of a syllable possibly of Scots Gaelic origin and of a syllable probably of immediate English origin (in any case, it is unrelated to the previous two words), and (4) the noun in the slangism put the kibosh on [...], which 
may come from the clogmakers' term with reinforcement from the Ashkenazic British English free collocation. The comprehensive version of the present article will try to sort out more words.

The present article, reduced from a comprehensive one in preparation, replaces the author's earlier remarks on our problematic word (Gold 1985b: 229, 1990b: 113, 1990c: 153, and 1992: 15).

\section{PART A}

\section{A.1. (i) the earliest evidence for our problematic word in the sense of 1. 'check, restraint' 2. 'veto' and (ii) a suggestion that "kye-bosk" is probably a misprint that has never been corrected}

The following truism bears repeating because many who have tried to etymologize our problematic word have been unaware of it: the first steps in etymological research are (a) endeavoring to gather all the written forms, the spoken forms, the meanings, and the collocational possibilities of the item under scrutiny, (b) trying to determine their relative age, and (c) trying to determine their absolute age. ${ }^{2}$

19th Century UK Periodicals, a searchable electronic database consisting of facsimiles of certain nineteenth-century British periodicals, contains this passage from The Age, a London newspaper:

The real cause of the "kiboshing" of the ex - Chancellor and his crew came out on Tuesday at Marlborough-street, before Mr. DYER. A chimney-sweep was convicted for having (according to the phrasæology of this Whig Act) "hawked the streets"-upon which his Blackness remarked:- "It vas the Vigs vot passed this Bill, and what the Duke of Wellington put the kibosh on "em for, and sarve "em right. It warnt nothing else than this here hact vot floored "em".-- Sooty is certainly a wiser man than WARBURTON WigGETT, alias, BulwER" ("Sweep Out the Whigs," which is a section of "Conservative Manifestations," The Age, 30 November 1834, p. 382)

We thus now have evidence for our problematic word from 25 November 1834 (= the Tuesday preceding 30 November 1834, which was a Sunday). His Blackness is a mock honorific that is modeled on His Highness and alludes to the typically soot-covered faces of chimneysweeps and Sooty $(=$ soot $+-y)$ is a derisive nickname, both of them having presumably been coined for the nonce, each of them deserving an entry in The Oxford English Dictionary (hereinafter OED). The passage, which contains one of the two oldest known uses of our problematic word (see two paragraphs below for the other one), deals with the trial of two non-Jewish chimneysweeps in the Magistrates' Court of London (no Jews seem to have been involved here in any way).

The passage just quoted also contains the verbal noun kiboshing, which implies the verb *kibosh (for which our earliest direct evidence is dated 1884), which implies the nonverbal abstract noun kibosh (as in put the kibosh [on...]). The fact that the reporter did 
not define either noun tells us that he felt readers would understand them, a feeling that could be based only on knowledge that at that time our problematic word in the sense of $\mathbf{1}$. 'check, restraint' 2. 'veto' had at least some currency (see later in this section for the same line of reasoning in another context). The quotation marks around the verbal noun can mean any number of things: he had just coined it (for the nonce?); if he did not, he considered it new; and he considered it slang.

Another London newspaper, The Observer, also had its reporter in the courtroom on 30 November 1834 and he quoted the chimneysweep as saying, "[...] the Duke of Vellington 'as put the 'Kibosh' on 'em” (p. 4), a passage to which Stephen Goranson has called attention (the verbal noun kiboshing is not used in that account of the court proceedings). Since here too we have quotation marks and no definition, either one reporter represented both newspapers or two reporters reacted identically to the word.

The second oldest known use of our problematic word is in The Sun (a London newspaper not yet available electronically). Dated 15 May 1835, the passage in question concerns the trial of a Western Ashkenazic Jew resident in London bearing the family name Myers, who was tried before the lord mayor of the city.

The third oldest known use of our problematic word is in Charles Dickens's sketch "Seven Dials". 3

"Seven Dials" first appeared in a London newspaper, Bell's Life in London, and Sporting Chronicle of 27 September 1835, where Dickens signed it Tibbs, a pen name he was to use throughout the series "Scenes and Characters" (published entirely in that periodical), of which "Seven Dials" was the first instalment.

Peter Bush has sent me a moderate enlargement of an excellent photocopy of "Seven Dials" as it appears in the original copy of Bell's Life in London, and Sporting Chronicle held at pressmark MLD14 in The Newspaper Library, a division of The British Library. Even when someone with 20/20 vision reads the photocopy with the naked eye, lowercase $\langle\mathrm{h}\rangle$ and lower-case $\langle\mathrm{k}\rangle$ are hard to distinguish because the sketch was set in bad type. Even the moderate enlargement does not help much. When, however, a magnifying glass is held to a moderate enlargement, the two letters are easy to tell apart: the fifty-ninth line of text in the first column ends with kye- and the sixtieth begins with bosh (the version of 1835 is unparagraphed; starting with Sketches by Boz, published by John Macrone in London in December 1836, the sketch has been divided into paragraphs, our problematic word occurring in the eighth). Whether the hyphen is soft (appearing in the text only because the entire word could not fit on the fifty-ninth line) or hard (because Dickens thought the word should always be hyphenated) is impossible to tell. ${ }^{4}$

Contrasting with the presumed unimportance of the status of the hyphen is the definite importance of this question: did Dickens intend the last letter of the word to be $\langle\mathrm{h}\rangle$ or $\langle\mathrm{k}\rangle$ ? The versions of "Seven Dials" published in 1835, 1836, and 1837 have $\langle\mathrm{h}\rangle$ whereas all versions beginning with the one published in 1839 have $\langle\mathrm{k}\rangle$. No manuscript or proofsheets of the sketch are known to have survived; the word does not appear, in any 
spelling, anyplace else in the Dickens corpus (= his published and unpublished writings, including letters and jottings); Dickens 1853 is silent on the word; the spelling with $\langle\mathrm{k}>$ has not been found in any primary document written by anyone else (on 11 January 1999, Edmund S. C. Weiner, of The Oxford English Dictionary, wrote me that "We have no evidence for kye-bosk other than its occurrence in 'Seven Dials" "); and no reliable evidence has been adduced for a pronunciation of the word with $* / \mathrm{sk} /$ rather than $/ \check{\mathrm{s}} / .^{5}$

Kye-bosk thus being a hapax legomenon not only in the Dickens corpus but also in all written and spoken English as we know it, we cannot be sure what spelling the writer intended, so that for all we know, $\langle\mathrm{k}\rangle$ could be a misprint for $\langle\mathrm{h}\rangle$. If, however, $* / \mathrm{sk} /$ turned out to be an authentic pronunciation (in the sense that it was not a spelling pronunciation), we would be faced with the question of which variant was older because that would have to be the one we would have to try to etymologize.

At least this much is clear at the moment: since older British English and later nonstandard British English have at least two examples of " $/ \mathrm{sk} />/ \breve{\mathbf{s}} /$ " (OED reports asch asche 'ask' for the thirteenth, fourteenth, and fifteenth centuries, ashe 'idem' for the fifteenth, and asshe for the fifteenth and sixteenth; Gerson 1967 records "ask > ash" in more recent nonstandard English; and Brook 1970: 127 gives another example of "/sk/ > /̌s/"), *“*kybosk > kybosh" would be possible phonologically if the word had an authentic $* / \mathrm{sk} /$-variant and it was older than the / $\breve{s} /$-variant, which is abundantly attested. In that case, all the etymologies proposed so far for our problematic word would fall because they involve only the latter variant.

If the $* / \check{\mathrm{s}} /$-variant turned out to the older one, it would continue to be the one to be etymologized, but we would be hard put to explain how word-final / $/$ / became word-final /sk/ because that change does not appear to be recorded in the annals of English diachronic phonology.

At least for the time being, then, we will work only with $/ \check{\mathrm{s}} /$. That it may have arisen as a result of the influence of the versions of "Seven Dials" published in 1835, 1836, and 1837 (and is thus a spelling pronunciation, hence not the variant with which we should work) is almost inconceivable since a hapax legomenon in a minor work of Dickens is unlikely to have had any effect on the spoken language. Moreover, that possibility is actually an impossibility because <sh> is attested for 25 November 1834 and 15 May 1835 , thus, before "Seven Dials" appeared in print.

In sum, $/ \check{\mathrm{s}} /$ is an authentic pronunciation (in the sense that it is not a spelling pronunciation), hence one with which an etymologist may legitimately work, unless reliable evidence surfaces for an older authentic pronunciation.

In Liberman 2010 we read the following: "[...] the strange form kye-bosk that Dickens used has to be accounted for. Could he have misheard it? Or did someone mispronounce the word that was so new at that time that its final shape had not yet solidified?"

For two reasons, the answer to both those questions seems to be "probably not":

1. Although certain Dickensians question or have in fact disproven the long-standing and by now widespread belief that the English of Dickens's characters is always utterly realistic (the Yorkshire English in Nicholas Nickleby, the East Anglian English of the 
Peggottys in David Copperfield, and the Cockney English in other works have been shown to be less than fully verisimilar, and the title of Gold ms. 3 speaks for itself), kyebosk or kye-bosk is unlikely to be another example of his imperfect imitation of nonstandard speech because speakers of English are unlikely to mishear English word-final / $/$ / as /sk/.

2.a. In any language, the speed at which one learns the meaning of a lexeme depends at least on (a) the nature of the lexeme and (b) the number of contextual and cotextual clues that help one understand it. For example, the meaning of a concrete noun such as bird can be learned faster than that of an abstract one such as idea because deixis ("See that bird?") is possible with concrete but not with abstract nouns (*'See that idea?"); or, the meaning of a non-monomorphemic noun such as tablecloth is easier to learn than that of a monomorphemic one such as door if the meanings of the elements of the nonmonomorphemic noun (table and cloth) are already known since the non-monomorphemic one is in that case motivated, that is, not arbitrary (see note 24), whereas the monomorphemic one is unmotivated.

2.b. Since by any descriptive or prescriptive standard Dickens in "Seven Dials" correctly used the idiom put the kibosh on [...], he must have encountered it at least a few times before 27 September 1835.

2.c. So far as is known, our problematic word had appeared in print only three times before Dickens published "Seven Dials". Consequently, unless earlier evidence for its frequent use surfaces in publications that Dickens was likely to read, we may assume that his chief and maybe sole encounters with it were not with its written but with its spoken form. According to the research literature, he often went to working-class neighborhoods and places where members of the working classes congregated (such as markets) to hear how they spoke so that he could make the English of his working-class characters as realistic as possible. On those expeditions, unless he spoke to the same shopkeepers and stallkeepers regularly, he was probably somewhat unlikely to hear the same people twice, unlikely to hear them four times, very unlikely to hear them five times, and so on. In consequence, since his use of the word was descriptively, prescriptively, semantically, syntactically, and stylistically correct, we conclude that he must have heard it at least several times and possibly from more than one person.

2.d. Having so concluded, we may go on to say that if Dickens misheard one person pronounce our problematic word (we will suppose for the sake of argument that he did), he was unlikely to mishear a second person and very unlikely to mishear a third person too. Likewise, if he correctly heard one person mispronounce it, he was unlikely to hear a second person do so, and very unlikely to hear a third person do so as well.

2.e. So far, we have spoken of Dickens's presumed encounters with our problematic word outside his own circle of family, friends, and colleagues. With respect to his own circle, we should first note that by 1853 at the latest he had come to have an aversion to slang (Dickens 1853 is a categorical rejection of it), but since the Dickens of 1835 (when he turned a mere twenty-three) was not necessarily the same person he was to be twenty years later, we cannot tell whether at the time of writing the sketch he already held slang to be the a sign of ill breeding (that his working-class characters used slang is irrelevant 
here), so that it is not impossible that had heard the word from one or more people in his immediate circle.

2.f. All of which is to say that Dickens, then living in the largest English-speaking city in the world, could have heard our problematic word on the streets of working-class neighborhoods, where he went to pick up usages he could incorporate into the speech of his working-class characters to make it ring true; possibly, he heard it within his own circle; and, possibly, he saw it a few times in newspapers. Possibly, he learned the idiom even before coming to London (from his birth in 1812 to 1817 he lived in Portsmouth and from the latter year to 1822 in Chatham).

2.g. Furthermore, in "Seven Dials" Dickens used our problematic word nonchalantly, that is, without putting it in quotation marks and without defining it (had he wanted to define it, he would have done so as all good writers of fiction do: not in a footnote, which would have been obtrusive, but by having the narrator or a character express the same thought in a second way, this time using a synonym or a circumlocution). Consequently, he must have been certain or he must have assumed that at least many of his readers would understand it. That certitude or that assumption could have rested only on knowledge that the word was at least fairly well known in the form and with the meaning we find in "Seven Dials" (see the fifth paragraph in this section for the same line of reasoning in another context).

Therefore, given our present knowledge, the best description of kye-bosk or kyebosk is "an accurate representation of a phonological variant otherwise unrecorded or an uncorrected misprint for kye-bosh or kyebosh".

Paul V. W. Schlicke, who is preparing an edition of Sketches by Boz, wrote me on 17 May 2011 as follows (brackets in original except where initialed D.L.G.):

'Seven Dials' was not included in the first [selected] series of Sketches by Boz, published in three editions by John Macrone in 1836 (twice) and 1837 [the preface in the third edition is dated 17 December 1836 (D.L.G.)]. It was revised for the second [selected] series of Sketches by Boz, published by Macrone in December 1836, and further revised for Macrone's second edition of the second series in 1837. It was subsequently revised four more times by Dickens for the Chapman and Hall collected editions of 1839, 1850, 1858, and 1868, as Scenes No. 5. Those are the major authorised editions. Other collections published by Chapman and Hall reprint one of those texts. Collections prepared by other publishers lack Dickens's authority. The sketch was also published (again without Dickens's authority) in the Athenaeum (31 December 1836) [excerpt], in the Monthly Review (February 1837) [excerpt], and in the Odd Fellow, vol. 1, no. 38 (21 September 1839), pp. 149-150.

The word kye-bosh, which appeared in the 1836 and 1837 versions of the sketch, was revised to kye-bosk in later editions.

A belief that kye-bosk is a revision is based on two assumptions: (1) Dickens found kyebosh or kye-bosh unacceptable and (2) $<\mathrm{k}\rangle$ is not a misprint for $\langle\mathrm{h}\rangle$. The assumptions seem unlikely because all our other evidence, both spoken and written, both from before publication of the sketch and from later, is only for /šs (the comprehensive version of the 
present article will discuss the unreliability of Baumann 1887 and 1902, which indeed give such a variant, presumably copied from "Seven Dials"). Therefore, unless new evidence changes the picture, we should continue to reason as follows: since Dickens, as proposed above, was unlikely always to mishear the word or to hear it mispronounced, either $\langle\mathrm{k}\rangle$ is a misprint or for some reason he wanted to swim against the stream by representing /sk/ instead of $/ \check{\mathrm{s}} /$; since no reason comes to mind why he should have wanted to be exceptional on this occasion, we are inclined to think that he intended $\langle\mathrm{h}\rangle$ (which the version of 1835 indeed has); hence by process of elimination we must conclude that $\langle\mathrm{k}\rangle$ was not his doing - a conclusion all the likelier in view of the fact that we cannot document from spoken English any pronunciation with $* / \mathrm{sk} /$ rather than $/ \check{\mathrm{s}} /$.

In sum, no evidence backs the supposition of a revision, though at least for the time being it cannot be ruled out because even the most logical of arguments against it could turn out to be wrong. Because all of us are groping in the dark with regard to Dickens's intended spelling of the word), no one can at the moment prove or disprove anything about the spelling kyebosk or kye-bosk, though we can say that it appears to be a hapax legomenon.

The poor printing in "Seven Dials" as it appeared in 1835 leads us to consider the possibility that the typesetter for the version of 1839 worked from the printed version of 1835 (rather than, as we would expect, either from the then most recently published one, namely, that of 1837, or from a fresh manuscript provided by the author) and, in so doing, he misread $\langle\mathrm{k}\rangle$ for $\langle\mathrm{h}\rangle$. To test the likelihood of that possibility, one would have to see whether, overall, the version of 1839 is closer to that of 1837 or to that of 1835 . The more it resembles that of 1835 and the less it resembles that of 1837 , the likelier the possibility that he indeed worked from the first printed version of the sketch (in which case we would wonder why Dickens felt the version of 1835 to be better than that of 1837). Schlicke's edition of Sketches by Boz will presumably facilitate comparisons of the published versions.

\section{A.2. Christopher Hibbert's misprints "kye-bock" and "hurray!"}

Page 133 of each of the five imprints of Hibbert 1967 cites as follows the line in "Seven Dials" where our problematic word occurs: "Hurray! Put the kye-bock on her, Mary!"

Because "kye-bock" is not found in any of the lifetime imprints of "Seven Dials" having Dickens's authority, in any posthumous imprint, or in any other primary or secondary source, and we have no oral evidence for the pronunciation implied by that spelling, we conclude that it is an uncorrected slip of the pen on Hibbert's part or an uncorrected misprint in the first imprint of his book that remained uncorrected in the four others too.

Since "Hurray" appears in no lifetime (and no posthumous?) imprint of "Seven Dials" having Dickens's authority, its status is presumably identical to that of "kye-bock": an uncorrected misprint in a secondary source. 


\section{A.3. $O E D$ misdated the spelling kye-bosk}

In the first and second editions of $O E D$, the oldest quotation for our problematic word is dated 1836 and reads as follows: "'Hoororar,' ejaculates a pot-boy in parenthesis, 'put the kye-bosk on her, Mary!'،

As we have seen in section A.2, the versions of "Seven Dials" published in 1835 , 1836, and 1837 have the spelling kye-bosh and only later ones, the earliest of which was published in 1839, have kye-bosk. Consequently, a member of the dictionary's staff must have found the above-quoted passage in a post-1837 version and either that person or someone else, knowing of the existence of the version of 1836 but not bothering to look at it, assumed that it had the same spelling as the post-1837 version and therefore "predated" the quotation, hence also the spelling kye-bosk, to $1836 .{ }^{6}$

\section{PART B}

\section{B.1. Yiddish khay and Ashkenazic Hebrew chay}

Alphabetic numerals (letters of the alphabet representing numbers) have been used at least in Aramaic, Armenian, Etruscan, Geez, Greek, Latin, Old Church Slavic, Rumanian, Sanskrit, and all Jewish-letter languages. For example, in Hebrew, alef $=1$, bet $=2$, gimel $=3$, dalet $=4$, and so on; in Greek, alpha $=1$, beta $=2$, gamma $=3$, delta $=4$, and so forth; and in Latin, $C=100, I=1, V=5, X=10$, and so on. ${ }^{7}$

Since giving alms to the needy is an act of justice, in post-Biblical Hebrew the word tsedaka 'justice; righteousness', not surprizingly, acquired the meaning 'charity, alms' (it now has both meanings), as a result of which none of the following is unexpected either:

1. Reflexes of that Hebrew word, such as Judezmo sedaka sidaka and Yiddish $d z$ doke $\sim$ tsdoke, mean 'charity, alms'.

2. The Hebrew saying tsedaka tatsil mimavet 'righteousness delivers from death' (Proverbs 10: 2) has in the post-Biblical Jewish world acquired a second meaning, namely, 'the giving of alms delivers from death'. As a result, tsdoko tatsil mimoves (the same saying romanized according to one of its Ashkenazic Hebrew pronunciations) is not infrequently inscribed on Ashkenazic almsboxes and dzdoko tatsil mimoves! dzdoko tatsil mimoves! [...] tsdoko tatsil mimoves! tsdoko tatsil mimoves! [...] is the typical cry of Ashkenazic beggars at Jewish cemeteries.

3. Because the letters chet and yod respectively occupy the eighth and tenth positions in the Hebrew alphabet, their numerical value is respectively eight and ten. Since they happen to be the root letters of the Hebrew adjective chay 'alive, living' (whence the Hebrew verb chayah 'live' and the Hebrew noun chayim 'life'), traditional Jews consider eighteen a lucky number. ${ }^{8}$ When those two letters represent the sum of eighteen, they are vocalized with the vowel patach (cardinal /a/): Yiddish khay, Hebrew chay (both $\langle\mathrm{kh}\rangle$ and $<\mathrm{ch}>$ represent $\left./ x /^{9}\right)$, the latter form being identical to the masculine singular form of the above-mentioned Hebrew adjective. 
Because traditional Jews, therefore, consider eighteen to be a lucky number, they strive to give charity or other monetary gifts in multiples of eighteen (eighteen pounds, thirty-six dollars, fifty-four zlotys, and so on), plant eighteen, thirty-six, fifty-four trees, and so forth in the Land of Israel in someone's honor or memory, set membership fees of organizations at multiples of eighteen of some unit of currency (Rivkind 1959 gives examples ss.vv. aynkoyfgelt 'membership dues' and khevre-gelt 'idem'), and so forth.

Thus, the idea is that a multiple of eighteen ensures the giver and, if there is one, a beneficiary or a living honoree a long, healthy, and good life. For example, in an article about donations received after Japan's largest earthquake by the Japan Society (headquartered in New York City), we read that "Some people gave $\$ 1,000$ and similarly large sums. But most gifts were much smaller: $\$ 50$ here, $\$ 25$ there. They came from the heart, not from a deep pocket. On occasion, there was a donation of \$18. It seemed an odd figure to Mr. Sakurai, until he learned that it meant the donor was probably Jewish. Jews often make charitable contributions in multiples of 18. In the Hebrew alphabet, letters have numerical equivalents. Eighteen represents 'chai,' Hebrew for 'life" (Haberman 2011; Motoatsu Sakurai was at the time president of the Japan Society). ${ }^{10}$

\section{B.2. Yiddish *pash and Ashkenazic Hebrew *pash}

The following tentative etymology is obtruded here with diffidence because Loewe 1924 offers a different one, which could be right (he and I agree that bash is a shortened form but we disagree on what it is shortened from and on its meaning; the comprehensive version of the present article will give details).

From the Hebrew verb root spelled $<$ pšt $>$ 'spread out, expand, extend' is derived the Hebrew adjective pashut 'plain, simple', a reflex of which is the Yiddish adjective poshet 'plain, simple', a substantivization of which is the Yiddish noun poshet 'pfennig (small German copper coin)' (so translated in Harkavy 1925: 381 and 1928: 381), the plural of which is pshitim 'pfennigs'. The abbreviation of that noun in both its singular and plural forms is spelled <pš'> (Rader 1950:475 mistakenly interprets the abbreviation only as 'pshitim', presumably because he found it only with the plural form). From that abbreviation an acronym, *pash, could have easily developed. ${ }^{11}$

*Pash could also be the acronym of the Ashkenazic Hebrew noun poshut (which has the same meanings as the Yiddish noun poshet), which comes from the Hebrew adjective pashut 'plain, simple', which comes from the Hebrew root mentioned at the beginning of the previous paragraph.

Presumably, Yiddish has the free collocation *khay pash 'eighteen pfennigs' and Ashkenazic Hebrew the free collocation *chay pash 'idem'. Each syllable of each of those collocations would have primary stress. Yiddish *khay pash presumably has a /p/-variant (*khay pash) and it definitely has a /b/-variant (khay bash). ${ }^{12}$

The name of the basic or the fractional unit of any currency can by analogy come to designate the basic or the fractional unit of one or more other currencies (whether or not the original meaning continues to be used). For example, Haitian goud, which originally 
meant only 'gourde', that is, 'the basic unit of currency of Haiti', later came to mean '[American] dollar' too (the word continues to have both meanings).

Since the above-mentioned Yiddish and Ashkenazic Hebrew free collocations and presumed numismonic acronyms could, therefore, easily refer to eighteen of the chief fractional unit of any basic monetary unit (eighteen cents, centavos, centimes, pence, and so on), we are not surprized that (originally Western) Ashkenazic British English has khay bash 'eighteen pence', which comes from regional Western Yiddish *khay bash 'eighteen pfennigs' (whether Ashkenazic British English has ever had *khay pash 'eighteen pence' remains to be seen).

For two reasons, that Ashkenazic British English word should be spelled khay bash: (1) The Standardized Yiddish Romanization, which applies to all lexemes of immediate Yiddish origin in Roman-letter languages, requires that spelling and (2) we need as clear a visual separation as possible between that word and the other English word or words spelled cibosh $\sim$ kaibosh $\sim$ kibbosh $\sim$ kibosh $\sim$ kybosh $\sim$ kye-bosh $\sim$ kye-bosk. Thus, khay bash has its own etymology, it has its own pronunciation, and now it has its own spelling too. $^{13}$

Although some details in the etymology of Ashkenazic British English khay bash 'eighteen pence' remain to be worked out, the major components of its derivation are clear, namely, the immediate etymon of that free collocation, the meaning and the origin of Western Yiddish khay, the fact that Western Yiddish bash is a numismonym, and the fact that it is in some way a shortening of a longer Western Yiddish form.

Consequently, the phrase "our problematic word" will hereinafter refer only to the other word or words the origin or origins of which remain to be elucidated. As we will see in section C.5, also to be separated out is the British English underworld (including prison) slangism kaybash 'sentence of eighteen months in prison' because its etymology too is, grosso modo, known: as the presence of the seme 'eighteen' makes clear, the word goes back in one or another to regional Western Yiddish khay bash 'eighteen pfennigs'. Again, the fact that details in its etymology remain to be worked out does not contradict or negate the statement just made and, whatever those details are, they will not affect our decision to dissociate the word from "our problematic word". Also to be separated out, in section C.6, will be the clogmakers' terms kybosh.

Inasmuch as 1. 'check, restraint' 2. 'veto' (as in the idiom put the cibosh kaibosh kibbosh $\sim$ kibosh $\sim$ kyebosh $\sim$ kye-bosh $\sim$ kye-bosk on [...]) is the earliest known meaning of our problematic word and may in fact be its earliest meaning (during its recorded history, it has definitely been its most frequent meaning), we will now endeavor to see whether a word or words meaning 'eighteen pence' could have yielded our problematic word when it means 1. 'check, restraint' 2. 'veto'. Other possible semantic connections (such as “*? 1. 'check, restraint' 2. 'veto' [?>] > 'Portland cement"” or "*?'Portland cement' > 1. 'check, restraint' 2. 'veto"') will be discussed in the comprehensive version of the present article.

To be addressed now are one question dealing with semantics and another dealing with phonology: 
1. Could a word meaning 'eighteen pence' yield a word meaning 1. 'check, restraint' 2. 'veto'?

2. Could Ashkenazic British English word-initial / $\mathrm{x} /$ (represented by $\langle\mathrm{kh}\rangle$ in khay bash) have become British English /k/ (represented by $\langle\mathrm{c}\rangle$ or $\langle\mathrm{k}\rangle$ in our problematic word)?

The first question is taken up in section C.1 and the second one in C.2.

\section{PART C}

\section{C.1. Is "'eighteen pence' > 1. 'check, restraint'. 2. 'veto"" possible?}

Herbert Martin James Loewe (1882-1940), of Western Ashkenazic ancestry at least in his male line, was born and raised in London. He was the third in his male line (after his father, James, and his paternal grandfather, Louis) to be extremely active in Jewish communal life in the United Kingdom and in Jewish scholarship (as was his son, Raphael). Those facts are noted here to establish his bona fides and, in his younger days, his first-hand familiarity with certain aspects of Jewish life in London (later he moved to Oxford and then to Cambridge, where he died). In the last paragraph of Loewe 1924: 245, he offered an entertainable answer to the question posed in the title of this section (though whether his etymology and etiology are right remains to be seen):

'Use. We now come to usage and the best illustration is afforded by Thomas Atkins's song 'We're going to put the Kaibosh on the Kaiser.' The metaphor comes from the small auctions in Petticoat Lane, where the bidding, for petty articles, rises, in pence or even in halfpence. An eager purchaser, to cut the proceedings short, will call out Khai Bash! and the article will promptly be knocked down to him. So, 'to put the kaibosh' on anything comes to mean to settle it or give the coup de grâce".

Since Loewe was writing before the Standardized Yiddish Romanization came into existence (in the 1940s) and was codified (Gold 1985a), he cannot be faulted, especially since "Khai-Bash" differs from khay bash in just three minor ways. ${ }^{14} \mathrm{He}$ did, however, make a serious mistake, as we will now see.

These mistakes are frequent in etymologies involving Yiddish:

A. Shortchanging the language by relegating it to a subordinate role (when in fact it is a link in the etymological chain just like any other link), as in "German via Yiddish > English" or "German (via Yiddish) > English" (instead of "German > Yiddish > English"), that is, as if Yiddish were not a means of human communication just like English and German or any other language but a humble handmaiden who deferentially passed linguistic items on a platter from one "real" language to another.

B. Not mentioning Yiddish at all when in fact it is a link in the etymological chain, for instance, "Hebrew > Polish" or "Hebrew > German" instead of "Hebrew > Yiddish > Polish" and "Hebrew > Yiddish > German" respectively. ${ }^{15}$ We see that mistake in Loewe's remarks: since "Hebrew > English" is possible only when speakers or writers of English are within range of the influence of spoken or written Hebrew (say, translators of the Jewish Bible into English who are working directly from the Hebrew parts of the text 
or speakers of English in Israel) and that is not the case here, our problematic word could not be of immediate Hebrew origin.

C. Even when Yiddish is correctly mentioned in an etymology, another mistake, less serious than the two just mentioned, is almost universal. Whereas etymologies involving other languages often specify not just a language but this or that variety of it (say, "European French > Canadian French > Canadian English" or "Norman French $>$ British English > Australian English"), Yiddish is so thoroughly terra incognita except to a dwindling handful that varieties of the language are almost never mentioned in etymologies in English dictionaries (as if the language were uniform diachronically, diatopically, diastratically, and in every other conceivable way) - despite that fact that every English item derived from Yiddish has at least one element pointing unmistakably just to this or that variety of the language. ${ }^{16}$

In the case of khay bash, for example, "Yiddish > British English" can be made more specific:

1. "Western Yiddish > British English" is better.

2. Since we are dealing only with the /b/-variant of Western Yiddish *khay pash, "regional Western Yiddish > British" is even better.

3. And best of all would be replacement of the word regional by a more specific label. Steven Lowenstein, who was the chief fieldworker for Western Yiddish at the Language and Culture Atlas of Ashkenazic Jewry, founded by Uriel Weinreich, tells me that the merger of $/ \mathrm{p} /$ and $/ \mathrm{b} /(\mathrm{as} / \mathrm{b} /$ ), of $/ \mathrm{t} /$ and $/ \mathrm{d} /$ (as $/ \mathrm{d} /$ ), and of $/ \mathrm{k} /$ and $/ \mathrm{g} /$ (as $/ \mathrm{g} /$ ) occurred in most varieties of Yiddish spoken in southern Germany (for example, peysekh 'Passover' and purim 'Feast of Lots' with /b/ in Ermeshausen and elsewhere), though / $/ \mathrm{k} / \mathrm{and} / \mathrm{g} / \mathrm{did}$ not merge there word-initially. When the relevant maps of the atlas become available, we will benefit from a better picture of the spatial distribution of the merger.

Yet even those refinements are not enough, for "English" means 'general English', which implies the English of all anglophones, yet since non-Jewish anglophones have rarely been in contact with Yiddish, more specification is needed: one or more varieties of Jewish English must be mentioned between Yiddish and English, for they are the indispensable link between Yiddish and non-Jewish varieties of English (see the seventh criterion in Gold 2009c: 241-244 and note 22 in the present article). Thus, Loewe should have proposed "Hebrew > Western Yiddish > Western Ashkenazic British English (? > Ashkenazic British English) > British English".

Liberman reacted to Loewe's etymology in this manner: "If this is what really happened at those auctions, the only conclusion can be that the word kibosh had firmly established itself, but no new light is shed on its origin. Nor are we told why the eager purchaser, rather than the auctioneer, had the right to terminate the bidding and how such an exotic shout, allegedly meaning 18p., worked as a magic formula. Let us also not forget the senses 'nonsense; fashionable stuff' and 'Portland cement.' Loewe's explanation has been repeated numberless times [...]".

Regarding the question of whether "the word kibosh firmly established itself," it would be good to specify a lect and a meaning so that we could tell which of the several 
words so spelled Liberman has in mind. If "firmly established itself" means "firmly established itself as the exclamation used to make an immediate bid of eighteen pence at auctions on Petticoat Lane and nearby streets', the word is khay bash 'eighteen pence', which was (originally Western) Yiddish when exclaimed by people speaking Yiddish and (originally Western) Ashkenazic British English when exclaimed by people speaking Ashkenazic English. The latter word could have spawned a non-Jewish variant, *kay bash 'idem', used by non-Jews present at the auctions conducted in Ashkenazic English or English who could not pronounce /x/ or, at least, not pronounce it word-initially (see paragraph A in note 13).

Although Loewe did not formulate his proposed etymology quite as the standards of Yiddish linguistics require, we have no reason to question his reliability in a different matter, namely, something he presumably saw with his own eyes and heard with his own ears - the small auctions on Petticoat Lane and nearby streets - especially since it is unthinkable that someone of his stature and accomplishments would contrive a story, put it into print, hence into mass circulation, and thus knowingly mislead countless people. Mind you, his etymology of the second element of Ashkenazic English khay bash could be wrong (he and I agree on the first one), he could have been wrong that the exclamation khay bash! at those auctions gave rise to our problematic word, and he could have been wrong on both counts, but, even if so, his remarks about what went on at the auctions should not raise doubt or arouse suspicion (though confirmation would be desirable).

How a bid of eighteen pence could put a stop to the bidding is easy to conceive, though I cannot prove the supposition about to be mentioned.

The street in London successively called Hogge Lane, Hog Lane, Peticote Lane, Petticoat-lane, Petticoat Lane, and, from no later than 1831, Middlesex Street (though to this day still known as Petticoat Lane informally) is on the legal boundary between Portsoken Ward (part of the City) and Whitechapel (part of the East End), which for a good part of the nineteenth and the twentieth centuries was home to a large, mostly Ashkenazic, working-class Jewish population. ${ }^{17}$ Probably every Ashkenazic Jew living there in the nineteenth century possessed Yiddish to this or that degree and/or Ashkenazic English to this or that degree and probably every Western Ashkenazic Jew living there at the time also possessed Ashkenazic German to this or that degree (Gold 1984b explains the difference between Yiddish and Ashkenazic German).

In light of the socio-economic conditions in Whitechapel in the nineteenth or twentieth centuries (it is still a working-class neighborhood, though probably no Jews live there now), we surmize as follows: (1) only items which residents of the neighborhood and others of comparable means found useful and relatively inexpensive were put up for auction ("small auctions [...] for petty articles"); (2) the auctioneers, therefore, earned little on every item sold; (3) consequently, they had to auction off as many as they could; (4) yet the bidding could rise "in pence or even in halfpence," which is to say, take a year and a day; (5) consequently, to move the merchandise along as quickly as possible, they permitted an immediate bid of eighteen pence; and (6) eighteen pence rather than less or more was chosen for two reasons: in the traditional Jewish world it is considered, as we 
have seen, a lucky number and the petty articles were not worth more than that (which precluded the selection of a multiple of eighteen pence as a maximum bid).

Those, it bears emphasis, are mostly assumptions. To make Loewe's etiology entertainable, we need not only confirmation of the two elements of his report (a bid of eighteen pence put a stop to the bidding and the bidder wanting to outbid everyone else called out khay bash!) but also proof that both those elements predate 25 November 1834 (or earlier, if older evidence for our problematic word is uncovered). Too bad he did not tell us why an immediate offer of eighteen pence stopped the bidding and how far back he remembered that custom; and too bad other readers of Notes and Queries who might have evidence for or against his explanation have not come forward.

\section{C.2. Is "non-English word-initial /x/ > English word-initial /k/" possible?}

Largely absent in Modern English, the phoneme /x/ does occur in Scots English (as in light, loch, might, and night, where it is represented by $\langle\mathrm{gh}>$ in words of English origin and $\langle\mathrm{ch}>$ in those of Scots Gaelic origin), South African English (in certain words of immediate Afrikaans or Dutch origin, for instance garingboom and gerook, where it is represented by $\langle\mathrm{g}\rangle$ ), and ethnolects with borrowings from substratal languages having that phoneme, such as the English of certain speakers of Arabic, Dutch, Greek, Hebrew, Judezmo, Spanish, Yiddish, and all Slavic languages.

Otherwise, the tendency in English is toward replacement of non-English word-initial / $\mathrm{x} /$ by $/ \mathrm{h} /$, as in "older Mexican Spanish juzgado > American English hoosegow," and certain words of immediate Yiddish origin in varieties of English not under the strong influence of Yiddish, examples being khale (which many anglophones out of range of Yiddish influence homophonize with the English noun holly and the English female given name Holly) and khutspe (see paragraph $\mathbf{E}$ in note 26), which many anglophones out of range of Yiddish influence pronounce with $/ \mathrm{h} /$ rather than $/ \mathrm{x} /$.

So far as I know, non-English word-initial /x/ has gone to English word-initial /k/ only in Sefardic British English - and I know of just one example: "Jewish Portuguese xamin 'a certain dish baked for the Sabbath' > Sefardic British English kamin 'idem,"18

However, to introduce Sefardic British English into the proposed etymology (*"regional Western Yiddish > Western Ashkenazic British English [? > Ashkenazic British English] > Sefardic British English > general English") would be unwise in light of (1) the fact that not one item in non-Jewish British English is known to be of Sefardic British English origin (influence of one lect on lect, at a higher level than the idiolect, is rarely limited to one item) and (2) the fact that no reflex of Ashkenazic British English khay bash has been reported for Sefardic British English (then again, since Sefardic British English has been allowed to dwindle almost of the point of disappearance without leaving more than a trace, the last argument may be weak).

Does our problematic word therefore have nothing to do with Ashkenazic British English khay bash and my etymology is wrong?

Or am I mistaken in thinking that "word-initial $/ \mathrm{x} />$ word-initial $/ \mathrm{k} /$ " is so rare in English that that change was unlikely to have occurred, say, when non-Jews present at the 
auctions on Petticoat Lane and nearby streets (surely not only Jews attended them) heard Jews shout khay bash! and adopted that exclamation as *kay bash!?

Or is our problematic word like English caliph, the etymology of which indeed shows replacement of word-initial $/ \mathrm{x} /$ by word-initial $/ \mathrm{k} /$ though at a pre-English stage in its history $?^{19}$ If it is, what precisely is that pre-English stage? The next section will suggest possibilities.

See the questions in paragraph $\mathbf{A}$ in note 13 for a bit more discussion.

\section{C.3. Yiddish word-initial /x/ > German word-initial / $\mathrm{k} /$}

Yiddish word-initial / $\mathrm{x} /$ has frequently become word-initial / $\mathrm{k} /$ in German (my additions are initialed d.-l.g. in Yiddish and D.L.G. in English):

[undz hern undz (d-lg)] nokh in 19tn y"h, az yidish-reyders in daytshland kenen yo aroysreydn [dem vortaynikn (d.-l.g.)] [x] un daytsh-reyders nit, afile nit di unterveltmentshn vos hobn "araynantlien" yidishe verter in zeyer daytsh. derfun shraybungen vi Kassene 'khasene', Kasser(t) 'khazer' ukhdoyme in Schwäbisches Wörterbuch 4, 251 un in andere daytsh-dialektishe mekoyrim lerov. ot iz a tsitat vos iz mideye vi vikhtik af toyfes tsu zayn di farzikhdikeyt fun der mayrev-yidisher fonetik keneged dem koteritoryaln daytsh: J. K. von Train, Chochemer Loschen, Meissen, 1833, VI: "Eine besonders schwierige Aufgabe für den Christen ist das $C h$ so auszusprechen, wie es nach jüdischer Mundart ausgesprochen werden sollte, daher von dem christlichen Gauner immer das $K$ gebraucht wird... so sagt zB. der Sprachkundige Chelek und der Gauner Keilich" (Vaynraykh 1957/1958: 119, ft. 5)

In translation,

Even as late as the nineteenth century [we hear (D.L.G.)] that speakers of Yiddish in Germany are able to pronounce [word-initial (D.L.G.] /x/ and speakers of German are not - not even denizens of the underworld, whose German contains so many borrowings from Yiddish (hence spellings such as Kassene 'wedding', Kasser(t) 'pig', and so on in Schwäbisches Wörterbuch 4, 251 [the Yiddish etymons are khasene and khazer respectively (D.L.G.)], which are abundant in other German dialectal sources). This passage is extremely important in understanding the independence of Western Yiddish phonetics from coterritorial German: J. K. von Train, Chochemer Loschen, Meissen, 1833, VI: "Since it is especially hard for Christians to pronounce $C h$ as it is in the Jewish dialect [von Train meant, of course, not the letters $C h$ word-initially, but [x] word-initially; if Yiddish is to be called the Jewish dialect, German will have to be called either the Christian dialect or the non-Jewish dialect (D.L.G.)], Christian denizens of the underworld always use $K$ [...] [for " $K$ " $\operatorname{read} / \mathrm{k} /$ (D.L.G.)]. Thus, for example, the linguistically proficient [= only Jews? (D.L.G.)] say Chelek [that is, Yiddish kheylek (D.L.G.)] and [Christian (D.L.G.)] members of the underworld Keilich".

More examples of Yiddish word-initial / $\mathrm{x} /$ reflected as word-initial $/ \mathrm{k} /$ in this or that variety of non-Jewish German are Cabber Kabber, Kabrusche, Kaddeschemune, Kaim, 
Kajes, and kalomes, which come respectively from Western Yiddish khaver, khavruse, khadesh-emune, khayim, khayes, and khaloymes. ${ }^{20}$

In sum, we wonder whether our problematic word could come immediately from this or that variety of non-Jewish German, in which case its German etymon would come from regional Western Yiddish khay bash 'eighteen pfennigs' (see note 12 and the text to which it is attached). In the next section, we will look at that possibility a bit more closely.

\section{C.4. Is "Hebrew > regional Western Yiddish > Dutch and/or German underworld slang > British English underworld slang > British English slang" possible?}

As suggested in the previous section, if regional Western Yiddish khay bash or both that word and Ashkenazic British English khay bash figure in the etymology of our problematic word, we may have to introduce some variety of non-Jewish German into the etymology to explain why Yiddish word-initial $/ \mathrm{x} /$ is reflected as word-initial $/ \mathrm{k} /$ in English. Yet if we did that, retaining Ashkenazic British English in the etymology would presumably become impossible, that is, the etymology would have to be *'Hebrew > Western Yiddish > Dutch and/or German underworld slang > British English underworld slang > British English slang," where no reasonable place appears to be possible for Ashkenazic British English (no other plausible etymology suggests itself that would include both non-Jewish German and Ashkenazic British English). Bringing Dutch underworld slang into the picture would be incompatible with retaining regional Western Yiddish khay bash in the etymology for a second reason too: the regional Western Yiddish phenomenon described in paragraph $\mathbf{3}$ in section C.1 is absent in Yiddish spoken on Dutch-speaking territory.

In any case, introducing Dutch and/or German underworld slang into the picture would imply contact between, on one hand, the British underworld, and, on the other hand, the Dutch and/or German underworld. ${ }^{21}$

Our problematic word, therefore, could be of immediate or of non-immediate Yiddish origin or, if our problematic word is actually more than one word (see the "Introduction" of the present article), one or more but not all of those words could be of immediate or non-immediate Yiddish origin.

Anyone supporting the suggestion that our problematic word comes immediately from Ashkenazic British English khay bash 'eighteen pence' might be tempted to quote (a) Loewe's remarks about etiology and (b) Weinreich's and von Train's about /k/. However, as just noted, they are incompatible with its each other: if Loewe was right, we are left with the phonological problem because German will not be in the picture (we should be reluctant to suppose that just one instance of Western Yiddish word-initial / $\mathrm{x} /$ became $/ \mathrm{k} /$, rather than $/ \mathrm{h} /$, in Western Ashkenazic British English or that one instance of $/ \mathrm{x} /$ in Ashkenazic British English became /k/, rather than /h/, in non-Jewish British English); and if we want to find attested examples of "Yiddish $/ \mathrm{x} />$ non-Yiddish $/ \mathrm{k} /$," the non-Yiddish language could be German (we have no evidence that it could be English), yet if we bring German into the picture, Loewe's etymology of our problematic word (hence also his 
etiology) must drop out, in which case we would be left with the problem of explaining why the history of our problematic word involves the number eighteen, that is, why eighteen pence rather than, say, six or twenty. A possibly correct solution to the phonological problem will be offered at the end of the present article (see the second paragraph of "To conclude (for the time being)".

In sum, if our problematic word has any Jewish connection, it is essential that we bring the number eighteen into the picture, but exactly how is not clear because whenever we try, a problem occurs. In the next section, we will try again, without, however, retaining my etymology or Loewe's etymology and etiology.

\section{C.5. Does the British English underworld (including prison) slangism kaybash 'sentence of eighteen months in prison' figure in the lineal ancestry of our problematic word?}

British English underworld (including prison) slang had (and still has?) kaybash 'sentence of eighteen months in prison'. 22 The formal and the semantic similarity of that word and of regional Western Yiddish khay bash 'eighteen pfennigs' makes clear that the English word is a non-immediate reflex of the Yiddish free collocation. This etymology may be the likeliest:

regional Western Yiddish khay bash 'eighteen pfennigs' > German thieves' cant [Rotwelsch] *kei Basch 'eighteen pfennigs' [see section C.3 on "Western Yiddish wordinitial /x/ > non-Jewish German /k/'] > British English thieves' cant *kay bash 'eighteen pence' > British English underworld slang *kay bash 'eighteen' > British English underworld (including prison) slang kaybash 'sentence of eighteen months in prison",23

We will now evaluate the probability of this semantic change, posited in that suggestion: “British English thieves' cant *kay bash 'eighteen pence' > British English underworld slang *kaybash 'eighteen' > British English underworld (including prison) slang kaybash 'sentence of eighteen months in prison'" (thus, first a broadening and then a narrowing of meaning).

Utterances that contain lexemes which may reasonably be interpreted in more than one way may foster semantic change. Bearing in mind the semantic changes which the foregoing etymology assumes, we will now consider these imaginary but plausible exchanges:

Exchange I:

Person A: "How much does it cost?"

Person B: "Eighteen pence".

Exchange II:

Person A: "How much does it cost?"

Person B: "Eighteen".

Person A: "Oh, I thought it was twenty". 
Person B: "No, it's eighteen".

Thus, when the context is clear, as in exchange II, the unit of currency need not be specified and no misunderstanding results (A's misunderstanding concerns the amount, not the unit of currency).

Now consider this imaginary but plausible exchange:

\section{Exchange III:}

Person A: "How much does it cost?"

Person B: "Kay bash".

Person A: "That's not much at all".

Person A, as we see from the third line, understood person $\mathbf{B}$, but we do not know whether person A took *kay bash to mean 'eighteen pence' or just 'eighteen' (in the latter case, with 'pence' being understood).

All else being equal, a monomorphemic lexeme is likelier than a non-monomorphemic one to change in meaning because, unlike the non-monomorphemic lexeme, it is unanalyzable semantically and thus less motivated, that is, more arbitrary than a nonmonomorphemic one. For example, though English shepherd (our earliest evidence for which is a text no younger than 1023) goes back to words meaning 'sheep' and 'herd' and English sheepherder (our earliest evidence for which is a dictionary published in 1871) also contains both those words, shepherd is easily old enough to have suffered so much phonological wear and tear, which it indeed has (see subsection VIII in section C.6 on another such pair of words), that its formerly clear bimorphemic status is now barely discernible (few of today's anglophones can say what its constituent morphemes once were), as a result of which it has become quasi-monomorphemic, the door therefore being open to the development of new meanings, which the word has indeed acquired, whereas sheepherder, being a much younger word, still has sharp phonological and morphological boundaries (sheep + herder $[=$ herd $+-e r]$ ), so that, not surprizingly, it still has only one meaning. ${ }^{24}$ Which is not to say that non-monomorphemic words with sharp morpheme boundaries cannot acquire more than one meaning - they can. We have in mind here just tendencies.

Anglophones will consider British English slang *kay bash 'eighteen pence' bimorphemic only if they know or guess that kay means 'eighteen' and bash 'pence'. Others, even though they might understand the collocation to mean 'eighteen pence', will be unable to analyze it and thus consider it to be monomorphemic, that is, as if it were kaybash (in the same way, say, that anglophones may know that the informal American English numismonym dime means 1. 'ten cents' 2. 'coin worth ten cents' but not that the word goes back to Latin decem 'ten'), so that in certain contexts (for example, in exchange III), it could be interpreted to mean either 'eighteen pence' or *'eighteen' and both interpretations on person A's part would be right if person $\mathbf{B}$ had pence rather than some other unit of currency in mind. 
The following semantic development is thus possible:

Stage 1. British English underworld slang *kay bash means only 'eighteen pence'.

Stage 2. As a result of its use in exchanges such as exchange III, in which everyone involved knows that pence are being discussed, that slangism comes to mean *'eighteen' as well. III:

Now consider this imaginary but plausible exchange, which is analogous to exchange

Exchange IV:

Person A: "How much time did the judge give him?"

Person B: "Kaybash".

Person A: "That's not much at all".

For the sake of argument, we will suppose that by the time exchange IV occurred, stage 2 had been reached and person B meant 'eighteen' (with 'months' being understand). Person A might have understood the word in the same way. Then again, person A might have understood not *'eighteen' but *'eighteen months'. If so, the way has been paved for this exchange:

Exchange V:

Person A: "What did the judge decide?"

Person B: "Kaybash".

Person A: "Eighteen months in prison — that's not much at all".

At that stage, we can easily imagine exchanges which, though even more elliptical, do not result in misunderstanding by either party:

Exchange VI:

An old prisoner to a new prisoner: "How much did you get?"

The new prisoner: "Kaybash".

The old prisoner: "That's not much at all".

In sum, the possibility of more than one interpretation of monomorphemic words in inexplicit utterances fosters the emergence of new meanings and *'"eighteen pence' > 'eighteen' > 'sentence of eighteen months in prison"' is therefore possible.

However, we could now not tack on to the end of that possible semantic change the meaning 1. 'check, restraint' 2. 'veto' because if we did, the resulting etymology would lack an etiology: we would be at a loss to explain why a (fixed or free) collocation meaning 'sentence of eighteen months in prison' rather than one meaning, say, 'sentence of death', was the immediate etymon of a word meaning 1. 'check; restraint' 2. 'veto'. That is, we would need an etiology, to replace Loewe's, to explain why the etymon he (or anyone else) suggested refers to the number eighteen (see too section B.1). 
More or less the same is true if we posit that the immediate source of our problematic word is German. In that case, it would be a cognate of Ashkenazic British English khay bash 'eighteen pence', which, if Loewe's etiology is right, could have reinforced use of our problematic word. In "To conclude (for the time being)," that Ashkenazic British English free collocation will indeed be suggested as a reinforcement, but the main etymon proposed is a clogmakers' term, which presumably has no Jewish connection.

"Etymologiseren zonder dateren van het materiaal is varen zonder kompas" (de Tollenaere 1983: 28) 'etymologizing without dating the material is like navigating without a compass' (for three examples, see note 35).

Dating, as far as possible, not only the genesis of our problematic word but also each of its meanings will help us see its history more clearly and thus more easily evaluate at least some of the many etymologies proposed for it.

For the moment, our evidence for kaybash 'sentence of eighteen months in prison' dates only to 1959 (see note 22), though it must be considerably older: because that meaning of the word contains the seme 'eighteen', it is obviously of some Ashkenazic Jewish origin (see sections B.1 and B.2), the three possible sources (whether immediate or non-immediate) being regional Western Yiddish, regional Ashkenazic German, and Ashkenazic British English; yet by 1959, British underworld (including prison) slang was closed to borrowings from all those sources as well as from Rotwelsch (which itself had largely gone out of use by then) and from Dutch underworld (including prison) slang; consequently, our problematic word in that sense must be appreciably older.

Anyone believing that 'sentence of eighteen months in prison' was the earliest meaning of our problematic word will have to show that that meaning predates 25 November 1834 or whatever the date of the earliest known use of our problematic word may be in the future. Mutatis mutandis, the same applies to a belief that this or that other meaning of our problematic word is the oldest (see section C.6 on *'lash, scourge, whip', 'iron bar [...]', and *'bludgeon, cosh, truncheon').

The etymology proposed at the beginning of this section rests on the existence of German thieves' cant *kai 'eighteen' or *kei 'idem' (that is, /kai/) and *Basch 'pfennig'. If we have evidence for those two words, we can straightforwardly assume that German thieves' cant also has the free collocation *kei Basch 'eighteen pfennigs'. If *Pasch but not $* B a s c h$ is attested, we can be fairly certain that $*$ Basch was used in the area of the intra-High-German merger of consonants (see note 12), in which case the free collocation kai Basch kei Basch must have been used too.

In sum, although details of the etymology of the British English underworld (including prison) slangism kaybash 'sentence of eighteen months in prison' remain to be worked out, its non-immediate Yiddish origin is clear, so that that word too is now separated out from our problematic word. 
C.6. A hypothesis (the earliest known collocation or collocations of a word may have to be considered in the evaluation of any etymology proposed for it) and three more suggested etymologies

To test the hypothesis enunciated in the title of this section, we will now return to the proposed etymologies discussed in sections C.1 and C.5 and also consider two more, namely, that our problematic word derives from (1) English kurbash 'whip [...]' (a word of Arabic and Turkish origin) and (2) the English clogmakers' term kybosh 'iron bar [...]' (a word consisting of an element possibly of Scots Gaelic origin and an element presumably of English origin), as well as a suggestion that it could also mean *'bludgeon, cosh, truncheon' (of unknown origin). In its earliest known uses, our problematic word appears in the first empty slot in the collocation put the [...] on [...], which seems to have always been its most frequent collocation.

We will first explain what is meant by the word comport in this section, then note the conclusions that one might draw from an examination of collocations when evaluating a proposed etymology, and finally see to what extent the five proposed etymologies discussed in the present article comport with the earliest known collocation of our problematic word.

Explanation of comport: Say that the only known meaning of word $x$ is 'symbol' and no earlier one is reconstructible; the earliest known collocation of word $x$ is "wave the [...]"; and we propose that the word is an immediate reflex of word $y$, which means 'banner, flag, standard'. In that case, the earliest known collocation of word $x$ comports with the meaning of the proposed etymon because "wave the banner" and "wave the flag" are grammatical collocations (we would therefore posit *'banner', *'flag', and/or *'standard' as the earliest meaning of word $x$ ). If, on the other hand, we traced word $x$ to word $z$, which means 'coat of arms', there would be no comportment because *"wave the coat of arms" is ungrammatical.

Possible conclusions of the collocations test: If the proposed etymology comports with the earliest known collocation or collocations, either the likelihood that the etymology is right is not diminished or it is enhanced. If the proposed etymology does not comport with the earliest known collocation or collocations, either its likelihood is diminished or the item we are trying to etymologize was from its very beginning used in at least one collocation that does not comport with the proposed etymology, in which case noncomportment does not diminish the likelihood that the proposal is right.

Thus, just as etymologists work with the earliest known or reconstructible form and meaning of the item under scrutiny, so too may it be necessary to examine its earliest known collocation or collocations. ${ }^{25}$ Since, however, no known collocation may be the oldest collection or the item may from its very genesis have been used in a novel collocation, the relevance of collocations in etymological research is not proven. ${ }^{26}$ That being a question for discussion and investigation (large numbers of indisputable etymologies in the world's languages will have to be examined to determine to what extent the hypothesis is, with or without modifications, right), we will, at least now, proceed on the assumption that a look at earliest known collocations may be useful. 
Do the proposed etymologies and the earliest known collocation comport? When reference is to bidding at auctions (see Loewe's etiology in section C.1), the appropriate English verb is bid (several semantically more specific verbs, which we need not consider, are by-bid, cap [the slang equivalent of by-bid], bid up, and bid in). It takes the preposition for when it has a direct object, as in "She bid quite a sum for the vase" and "They bid six thousand dollars for the book," and either for or on when it has no object, as in "She bid for the vase" "She bid on the vase".

When reference is to a prison term (see section C.5), the appropriate verbs are condemn, put away (an informalism), and sentence, the first and third of which take the preposition to and the second of which takes for, as in "The judge condemned him to life imprisonment," "The judge put them away for ten years," "The judged sentenced her to a year".

The collocation put the [...] on [...] is thus not used in connection with bidding at auctions or with sentencing someone to time in prison (or with imposing any other kind of sentence). ${ }^{27}$

To be presented now are two rather recent etymologies proposed for our problematic word in the sense of 1. 'check, restraint' 2. 'veto' and one that may not have been suggested before. All three will be put to the collocations test (however, since the validity of the test has not been proven, failure to pass the test will not be held against any proposal).

Stephen Goranson proposes that the word comes from English kurbash 'whip about a meter long made of hide of the hippopotamus or rhinoceros and once used as an instrument of punishment at least in parts of the Muslim world', which we will here quasiantedate to 1801 (the earliest quotation in $O E D$ is from 1814), and which has been spelled in at least ten ways: coorbatch $\sim$ corbage $\sim$ courbache $\sim$ courbash $\sim$ curbash $\sim$ koorbash $\sim$ korbash $\sim$ kourbash $\sim$ kurbasch $\sim$ kurbash (the spelling kurbash is used in the present article to represent the word in all its pronunciations and spellings). ${ }^{28}$

Goranson calls attention to a printed broadside called "Penal Servitude," a (unique?) copy of which is held in the FitzGerald Collection of the National Library of Australia (Ferguson 1941-1986). There, our problematic word and the noun lash 'whip' appear within one line of each other - a co-occurrence which, Goranson proposes, is evidence that the earliest meaning of our problematic word was *'whip', a meaning which is in turn evidence that our problematic word is a spelling and pronunciation variant of kurbash. ${ }^{29}$ The relevant part of the text of the broadside reads as follows:

There is one little dodge I am thinking, That would put your profession all to to smash, It would put on the kibosh like winking That is if they was to introduce the lash.

Here are a few thoughts: 
I. Co-occurrence, proximity, juxtaposition, or apposition is not always a sign of synonymy, though the occurrence of one or the other in an utterance should prompt us to pay serious attention to a proposal such as Goranson's.

II. The words That is introduce a clarification, but of what kind is not evident: (1) do they signal that the writer is synonymizing kibosh and lash (as Goranson proposes they do) (2) if our problematic word in the sense of 'check, restraint' was already in use when the text was written (in which case his proposal falls), (2.a) do they introduce a specification of the check or restraint that could be put on people's behavior (the lash) or (2.b) is kibosh here a spelling of kurbash induced by the spelling of kibosh 1. 'check, restraint' 2. 'veto'? Since we do not know when "Penal Servitude" was written or published or who wrote it, no answers are possible.

III. The collocation put on the kibosh is extremely close to the one familiar to us, put the kibosh on [...] (for the meaning of like winking, see sense 4 of winking vbl.sb. ${ }^{1}$ in $O E D)$, but that fact does not prove, as we will now see, that Goranson's proposal is right.

IV. Definition 46b of put on in $O E D$ is 'To impose or inflict as a burden or charge. In quot. 1588, to "lay on as a blow" [single quotation marks in original (D.L.G.)] (Schmidt)'. The quotation dated 1588 is from Shakespeare's Loves Labour Lost IV.i.116: "Finely put on indeede". A more generous quotation than the one in $O E D$ will be more informative (especially the quotations chosen for the first edition of the dictionary are usually too short to be useful in etymological research or in understanding the lexeme or meaning in question): "My lady goes to kill horns, but, if then marry, / Hang me by the neck if horns that year miscarry / Finely put on!" (The Yale Shakespeare, lines 114-116, spoken by Boyet in reaction to Rosaline's "Why, she that bears the bow. Finely put off!").

Definition 46k of put on in $O E D$ is 'To bring into action or operation; to cause to act; to apply; to exert' [...] Also in fig. applications'. The quotation with a figurative example is dated 1889: "And would soon be bankrupt if I didn't put on the screw occasionally".

Presumably, the broadside contains put on in one or both of those senses, but, even if it does, that fact would not warrant the conclusion that kibosh necessarily means 'whip' there because the meaning 1. 'check, restraint' 2. 'veto' would be just as compatible with definitions 46b and 46k as 'lash, scourge, whip' would, so that "put on the kibosh" in the text could just as easily mean *'put on the restraint' as *'put on the lash'.

V. We wonder whether the fact that none of the at least seven spellings of our problematic word is identical to any of the at least ten of kurbash speaks against Goranson's proposal. Or is kurbash the etymon of our problematic word and the absence of any identity is merely a sign that awareness of the etymological connection between the two words eventually disappeared?

VI. So far, then, the proposed etymology is still entertainable but not proven and the chief obstacle to progress in evaluating the importance of the broadside is the fact that we do not know when the text of "Penal Servitude" was written.

VII. If in the world of real-estate agents the mantra is location! location! location! 'the location of a piece of property is highly important in determining its value on the market' and practice! practice! practice! is the mantra in the world of music ('if you want to succeed as a musician, practice intensely'), one of the mantras of everyone serious about 
etymology is transmission! transmission! transmission!, that is, one has to demonstrate not only that the form and the meaning of the suggested etymon could have yielded the form and the meaning of the suggested reflex (= phonological and semantic criteria) but also that at least certain users of the receiving lect were likely to be or definitely were within range of the influence of the suggested source lect. In certain circumstances, one person's exposure to the donor lect is enough to launch a new usage in the receiving lect, which is to say that the butterfly effect is not unknown in the history of human language (compare note 1$).^{30}$

English kurbash 'whip [...]' designates something which seems to have always been exotic in the British Isles (and all other anglophone countries), hence something presumably known just to people who saw or heard about that kind of whip while traveling in Muslim countries or living there, who heard about it from people returning from there, or who read about it in letters, books, and/or periodicals. For Goranson's proposal to be entertainable, the word would have had to be at least fairly well known in the British Isles before 25 November 1834, yet the available citational evidence could hardly be scantier:

The only pre-1834 quotation in $O E D$ is from the pen of William Brown ("A Corbage, which consists of a strap of the skin of the hippopotamus, about a yard in length" [Brown 1814, vol. 1, p. 586]), who, relying on Antes 1801 or 1802, was relating the torture of John Antes (1740-1811), an American Christian clergyman who arrived in Egypt in November or December 1769 to minister to the Copts. In an effort to extort money and other valuables from him, Mamelukes made him their prisoner in November 1779, tortured him with the bastinado, the kurbash, etc., etc., etc., and then released him. In 1781 Antes left Egypt for Great Britain (idem, pp. 571-589). Brown does not mention any uproar over the incident.

The word appears twice in Antes 1801: 121 and 1802: 121 not as English but as quoted Arabic (though Antes is likely to have used it as an English word when speaking English, at least after the incident and maybe also between his arrival in Egypt and the incident): "Then they brought a strong staff about six feet long, with a piece of iron chain fixed to it with both ends; this chain they throw round both feet above the ankles, and then twist them together, and two fellows on each side, provided with what they call a corbage, hold up the soles of the feet by means of a stick, and so wait for their master's orders". The word stroke on page 122 tells us that corbage indeed means 'kurbash': "They then laid on me roughly, and every stroke felt like the application of a red-hot poker".

Antes writes further that "There are two methods of giving the bastinado among the Mamelucks in Egypt [...]. The one is given upon the soles of the feet, with the so called corbage, which instrument I have described in my dissertation upon the Nile, on page 121" [...]. The operation is called receiving, sometimes eating the corbage" (pp. 130-131). The words "they call," "so called," and "is called" show that Antes is speaking about an Arabic, not an English, word.

The second quotation for kurbash in $O E D$ being dated 1842, it is not relevant here.

Thus, we have several quasi-quotations (all from Antes's pen) and Brown's definition (based on his reading of Antes 1801 or 1802), which is to say, evidence not for an English 
word but for an Arabic one. An excellently composed dictionary would put such quotations in brackets and indicate that they are for an alloglottal usage. Are the gatherers for $O E D$ not provided at least with guidelines? If any of Antes's letters have survived, it would be good to see whether he used the (Arabic? English?) word there too.

Although $O E D$ does not publish all the quotations in its files (at least not in the print versions of the dictionary), it does strive to present a chronological spread if space permits: "about one for each century though various considerations often render a larger number necessary" (OED, vol. 1, "General Explanations, p. xxviii). One of those considerations, relevant here, is the estimated age of the item. The younger it is assumed to be, the more misleading a spread of "about one for each century" would become. Here is a hypothetical example: if the first edition of $O E D$ gave just one quotation, dated 1901, for an item coined in that year and in widespread use ever since then, the requirement of "about one for each century" would be met but the dictionary would create the misimpression that the item was ephemeral, possibly a nonce formation (not surprizingly, therefore, in $A$ Supplement to the Oxford English Dictionary [hereinafter OEDS], published in four volumes between 1972 and 1986, we read that "the entries for words entering the language in the twentieth century are [in this supplement (D.L.G.)] more generously illustrated by examples than was judged necessary in the past" [vol. IV, 1986, p. x]).

We therefore expect that had the staff of the first edition of $O E D$ found pre-1842 evidence besides the passage in Brown 1814, it would have printed it. Yet it published nothing else. However, to give Goranson's proposal the benefit of the doubt, let us assume that the expectation is unjustified. If so, we can fall back on a different line of reasoning.

One of the purposes of $O E D S$ is to publish quotations which (1) the readers for the first edition did not find, (2) arrived in Oxford too late to be included, (3) were held back because they illustrated lexemes or meanings which the staff of the first edition of $O E D$ and that of the supplement of 1933 held to be obscene, or (4) are from more recent sources, which the earlier staff could not possibly have seen. Many of those additional quotations appear in $O E D S$ in order to avoid creating the misimpression that certain usages in $O E D$ are obsolete. For instance, the only quotation for Miltonism in the first edition of $O E D$ is dated 1802. No additional quotations appear in the Supplement of $O E D$ published in 1933. The second volume of $O E D S$, published in 1976, has two: one dated 1936 (actually, for the variant Miltonicism) and the other dated 1938. Omitting both of them from $O E D S$ would have created a misimpression of obsoleteness and giving just one, a misimpression of extreme rarity.

The foregoing remarks are preliminary to the following.

We come now to the "different line of reasoning". The quotations for kurbash in the first edition of $O E D$ are dated 1814, 1842, 1866, 1884, 1885, and 1892. OEDS, which includes the supplement of 1933 , contains none. That means that no antedatings were found (antedatings are automatically in historical dictionaries, etymological ones, and historical-etymological ones to avoid creating the misimpression that an item is younger than it really is), no postdatings were found (postdatings are automatically included to avoid creating the misimpression that an item is obsolescing or obsolescent), and, probably, no quotations dating to between 1814 and 1892 were found either (probably at 
least a few of that type would have been included, had they been found, to show that kurbash was not so sporadic as those six might suggest).

All things considered, we conclude that kurbash is an exoticism which is likely to have enjoyed only a fair amount of use, probably just during the second half of the nineteenth century, solely among people with at least a fair amount of formal education. ${ }^{31}$ Which is to say, too late to be the etymon of our problematic word. However, to give Goranson's proposal the benefit of the doubt, we will continue to consider it entertainable if anyone can show in what circumstances kurbash, in any spelling or pronunciation, could have become our problematic word.

The degree to which the pronunciation of a word changes usually depends at least on its age (the older it is, the likelier it is to change), the extent to which it is spoken (largely written words may not change much in pronunciation, if at all), and how fast the phonology of the language itself changes. In the case at hand, we wonder how kurbash, being a word of presumably low frequency before 25 November 1834 AND with an exotic referent, could before that date have been so prominent anywhere in the British Isles or in any anglophone circle (say, politicians) that it gave rise to a figurative usage (as Goranson's proposal implies) and how, in its figurative sense, it could have been so frequent in speech that its pronunciation changed to such an extent that awareness of the etymological connection between it and our problematic word eventually disappeared (see paragraph $\mathbf{V}$ above). To say nothing of the fact that time would have been needed for the word to percolate from worldly circles (readers of periodicals and so on) to the less worldly ones.

In sum, the available citational evidence, namely, the fact that the earlier known use of the ENGLISH word kurbash is dated 1842, speaks strongly against Goranson's proposal, but we should keep an open mind and therefore be ready to hear counter-arguments.

If anyone has preceded the present author in publishing any part of the following etymology, it would be good to have details.

Douglas Wilson calls attention to this passage in Lloyd's Weekly Newspaper of 14 October 1860:

I did not speak to Bamforth. I did not challenge him to fight, nor did I strike him down. I know what a kybosh is (a laugh). It is a piece of iron about a foot long, but I did not use one.

The speaker was a clogmaker (maker of wooden-soled shoes) who, after being physically attacked by other clogmakers, was testifying against them in Clerkenwell Police Court (Clerkenwell is an area of central London). Since the newspaper's account of the proceedings do not show that someone asked him to define the count noun kybosh, he must have been self-motivated to do so. The only motive we can think of is that he knew kybosh was a clogmakers' term whereas now he was addressing men of the law who were not clogmakers, so that a definition was in order lest they not understand.

The fact that someone laughed as soon as the concrete count noun kybosh was uttered and did so before the witness defined the word is significant too. Since the laugher is not identified, he (women were unlikely to be present) could not have been someone whom 
the reporter could readily identify (such as the judge). Rather, the laugh must have come from someone who knew the word and its meaning and did not stand out in the courtroom. That person could easily have been another clogmaker, who would have been either one of the defendents or a spectator. In any case, since the laugh implies that the laugher recognized the word, we may conclude that kybosh was not the witness's idiolectalism.

Also worthy of consideration is the reason for the laugh. Presumably, the laugher found it amusing that the tool could be used, or perceived to be usable, as a weapon. Maybe he also found it ironic that one clogmaker might assault another clogmaker with one of their own tools. Later, we will return to that laugh of 152 years ago.

Having formulated the foregoing tentative explanation (for which I could find no support in the dictionaries or other works of reference at hand), I turned to the International Museum of Clogs (Internationaal Klompenmuseum), in Eelde, The Netherlands, whereupon, Jan Tent, a conservator, got in touch with Trefor Owen, a master clogmaker in Criccieth, Gwyneed, Wales, who had learned the traditional way of making clogs from two elderly clogmakers in England (a Lancashireman and a Yorkshireman) and later opened his own business (in 1978). He wrote Tent as follows on 5 February 2012:

"Clogmakers over the age of about sixty-five will recall the process called boshing, bosching, or sometimes burnishing, that is, the rubbing of waxed and oiled leather (to make it easier to shape over the last) with a hot iron bar, which, when not in use, usually rests on a bracket over a gas flame. Boshing was the custom when all makers of clogs used a block last (a solid last) and not the modern spring last. Since rubbing the waxed and oiled leather with the bar was usually the last step in making the uppers, it could be interpreted as putting the final touches on it, which is to say, finishing it". Before the availability of gas, the tool must have been kept over a fire.

Owen 2010 supplements the foregoing letter - boshing is "the process of shaping and smoothing down the waxed kip uppers of a clog over the last; it softens the wax, smooths the leather down onto the last, and then, as the wax resets, it holds the shape created" and it contains a term — boshing tool — which is presumably a synonym of the concrete count noun kybosh.

The verbal noun boshing $\sim$ bosching implies the transitive verb bosh $\sim$ bosch. The fact that burnish and bosh bosch are not only synonyms (to bosh the leather is thus to burnish it) but are also alike in sound suggests, but does not prove, that they are etymologically related to each other. Since the etymology of burnish is almost completely clear (< Middle English < Old French $<$ an unidentified Germanic language $<$ Proto-Germanic < Proto-Indo-European) and it does not involve bosh $\sim$ bosch, the genetic relationship between the synonyms, if such a relationship exists, would be "burnish > bosh bosch," not vice versa. Supporting the assumption that the phonological development would be from the word with more syllables to the one with fewer would be the remark in section $\mathbf{C . 5}$ about shepherd and sheepherder: the more a word is spoken, the more it is subject to phonological wear and tear, so that clogmakers, often using the word burnish, were likelier than the rest of us to reduce it (unless you're a traditional clogmaker, try to recall how many times you've spoken the word burnish). 
From Owen's use of the word sometimes, we infer further that burnish came to be a formal word among clogmakers, a word used possibly just with outsiders (we can easily imagine a clogmaker explaining to a nonclogmaker, "We call that boshing, which is to say, burnishing").

The spelling bosch is either an older spelling of bosh (older English texts contain many examples of $<\mathrm{sch}>$ representing / $/$ / where today's English has $<\mathrm{sh}>$, as in bash, dash, and mash), a spelling induced (during World War One?) by Bosch (a pseudoGerman spelling variant, induced by the meaning of the word that follows, of the English ethnophaulism Boche 'German', which comes from the French ethnophaulism Boche 'idem', which is unrelated to burnish), or both.

Another part of the puzzle - a big part of it - whence our problematic word in the sense of 1. 'check, restraint' 2. 'veto'? - may now have been solved: Owen's words "the last step [...], putting the final touches on them, [...] finishing them" remind us of the meaning of the idiom put the kibosh on [...]. Naturally, for the name of the tool to be the etymon of our problematic word in that sense, it would have to have been in existence before 25 November 1834 or whatever the earliest date of its first known use may be in the future.

Whether or not our problematic word has now yielded up a big part of its long-held secret, this question remains: how do we get from the clogmakers' technical term bosh bosch to the clogmakers' technical term kybosh, which is to say, what is the meaning or function of $k y$ - and what is the origin of that morpheme? Is it another spelling variant of the morpheme $\mathrm{ca}_{-} \sim$ che- $\sim \mathrm{co}-\sim \mathrm{ka}-\sim \mathrm{ke}-\sim$ ker- (as in kerfluffle and kerplunk), which, though said to be an Americanism (by origin? by survival?), may be of Scots Gaelic origin and could thus be present at least in the English of Scotland and northern England too. Two data seem to tell us that kybosh as a clogmakers' term could well have arisen in northern England:

1. Two entries in $O E D$ relevant to the making of clogs mention northern England (but no other area): $c \log$ 'A shoe with a thick wooden sole protected by a rim of metal, worn in the north' (sense 6.b) and clogger 'One who makes clogs, or wooden soles for shoes. (A distinct trade in the north)'.

2. Owen learned the traditional way of making clogs from two elderly northerners (Yorkshire and, even more so, Lancashire are in the north of England), who by the 1970s were presumably among the very few of the traditional British clogmakers. When an element of culture dwindles, be it an article of clothing, a language, or a craft, usually it will last longest where it has been most frequent.

It would thus seem that clogs have been worn more in northern England than anywhere else in the British Isles and that the traditional way of making them survived in that region longest. If so, those facts would comport with the possibility that $k y$ - is a spelling variant of a morpheme possibly of Scots Gaelic origin and we would suggest further that the name of the tool was coined in northern England.

A further suggestion is that the exclamation khay bash! at auctions In Petticoat Lane and nearby streets could have reinforced use of idiom put the kibosh on [...], in which case the problem of " $/ \mathrm{x} />/ \mathrm{k} /$ " (see subsections C.2 and C.3) would be solved (the $/ \mathrm{k} /$ of our 
problematic word would come, straightforwardly, from the clogmakers' term and only from it) and the exclamation need not be older than our problematic word (just the name of the tool would have to meet that requirement) because reinforcement could have come at any time after the emergence of the idiom (indeed, reinforcement, by definition, always postdates the birth of the item reinforced).

The reason I see only the clogmakers' term and the exclamation as being possibly relevant to the history of the idiom is the fact that both connote finality whereas kaybash 'sentence of eighteen months in prison' does not (the 'black cap' etymology proposed for our problematic word, to be examined in the comprehensive version of the present article, also connotes finality; whether it was also a reinforcer will be discussed there) and the reason I see the clogmakers' term as playing a larger role than the exclamation is that the making and wearing of clogs in the British Isles go back at least to 1416 (see OED s.v. $\operatorname{clog}$ ) and the fact that until the mass production of clogs began, that is, in factories (in the early nineteenth century?), people making them worked alone or in small groups, so that for centuries the public had easy access to their workplaces (where it had to go to buy them), as a result of which numerous nonclogmakers could have become familiar with a kybosh and learn its name and, if the idiom arose among clogmakers, with the idiom as well, whereas the auctions on Petticoat Lane and nearby streets were considerably younger (if any Ashkenazic Jews were living in London before the 1690s and if the auctions began before the nineteenth century, no records of them appear to have survived) and exclamation of khay bash! may not have been frequent. Which is to say that clogmakers using kyboshes were likelier than exclaimers of khay bash! to be linguistically influential. The fact that our problematic word was used in the northern part of Ireland before 1884 and in Cornwall before 1895 (see section C.7) should make us skeptical of a derivation solely from the exclamation but not of a derivation just from the clogmakers' term (with or without reinforcement from the exclamation). Broadcasting power is a useful term in etymological research.

The foregoing suggested etymology might not pass the collocations test. Unable to determine the usual collocation or collocations for the clogmakers' term kybosh, I can only guess that it might be *"roll the kybosh over [the leather]" and/or *"put the kybosh to [the leather]," neither of which would be identical to "put the kibosh on [...]," though the second one comes close. Older traditional clogmakers might be able to enlighten us on the actual collocation or collocations and written sources might help too.

Alternately, one could assume that the original name of the clogmakers' tool was *bosch $\sim$ *bosh (< the verb bosch $\sim$ bosh [that is, by zero alteration] < the verb burnish), which became kybosh under the influence of our problematic word (if so, we are back at square one as far as the origin of the last-mentioned word is concerned).

In any case, during the late eighteenth and early nineteenth centuries, a significant number of people in the British Isles were engaged in the making of clogs (in northern England, it seems, intensely), so that it would not be surprizing were a clogmakers' term to come into use in working-class British English in a figurative sense, whence the word in that sense (but not necessarily in its literal one) could have passed into other 
varieties of the language. If so, it is easy to see why the etymology of our word was almost lost: since the traditional way of making clogs has almost disappeared, so too has knowledge of many or most of the terms associated with it. Luckily, however, at least one of them and its meaning have now been saved from oblivion.

The formal similarity between the concrete count noun kybosh, that is, the clogmakers' term, and the British English informalism cosh (a borrowing of Romani kosh 'stick' and/or a shortening of Romani koshter 'stick') seems to be coincidental.

Michael Quinion, who reported Wilson's find, has suggested that the original meaning of our problematic word might be *'bludgeon, cosh, truncheon' (Quinion does not propose an etymology). For three reasons, that possibility is unlikely:

1. A kybosh is much likelier to be pressed into service as a bludgeon (presumably the incident reported in the newspaper) than a bludgeon is to be pressed into service as a kybosh.

2. Since the etymology of burnish is established, it is a given here. Since the etymology *"burnish > bosh bosch > kybosh" (as clogmakers' terms) is at least possible (or is it probable or certain?), it could be a second given. If for the sake of argument we assume it to be a second given, interpretation of kybosh as the name of a clogmakers' tool follows logically from those givens. Interpretation of the word as *'bludgeon, cosh, truncheon' would not.

3. Inasmuch as the following utterance should not elicit laughter, the laugh in court would be inexplicable if the witness used the word in the sense of *'bludgeon, cosh, truncheon': *'I did not challenge him to fight, nor did I strike him down. I know what a bludgeon [or a cosh or a truncheon] is. I did not use one'.

Since the collocations "put the bludgeon on [...]," *"put the cosh on [...]," and "put the truncheon on $[\ldots]$ " sound ungrammatical, the proposal does not appear to pass the collocations test.

\section{C.7. Do three entries in Joseph Wright's The English Dialect Dictionary speak for or against any proposed etymology?}

Wright 1895-1905 has these three entries (I have modernized the typography, fleshed out the bibliographical references, and made the entries more informative without changing their substance; the comments after two entries are mine):

kibosh verb Ireland. 'end, finish, put a stop to'. northern Ireland. "Thin the Rector pull'd out an' oul' fourpenny-bit / (For the fourpenny-pieces wir current as yit) / An' handed the pill that wid kibosh the fun" (Cruck-a-Leaghan and Slieve Gallion, Lays and Legends of the North of Ireland, London, Houlston \& Sons, Edinburgh and Glasgow, J. Menzies \& Co., Dublin, M. N. Gir \& Son, 1884, p. 87) [vol. III, p. 431] 


\section{Comments:}

1. Why did Wright give the word two spatial labels and how are we to interpret each of them individually and both together? Was the north of Ireland or northern Ireland of 1884 the same territory as the Northern Ireland of today?

2.In a footnote, Cruck-a-Leaghan and Gallion define the word as 'end; put a stop to'. 'Finish' is thus Wright's addition.

3. The entry and the next two should be cross-referred.

kybosh $^{1}$ substantive ${ }^{1}$ Cornwall (manuscript collection of T.C. Peter) [kaibos] 1. 'wages'. 2. 'money'. See kibosh and kybosh ${ }^{2}$ [vol. III, p. 490]

kybosh $^{2}$ substantive ${ }^{2}$ Cornwall 'affectation, display, pretence'. "When next I have a shiner [sweetheart] / No more kybosh for me / Some slawterpooch I'll marry / Who'll ever constant be" (Joseph Thomas, Randigal Rhymes and a Glossary of Cornish Words, Penzance, F. Rodda, 1895, p. 25; manuscript collection of Margaret A. Courtney). See kibosh and kybosh ${ }^{1}$ [ibidem]

\section{Comments:}

1. The interpolation "[sweetheart]" is Wright's.

2. The word shiner 'sweetheart', rather than being from German scheine 'pretty one [female]' and/or Yiddish sheyne 'idem', is in all likelihood from English shiner 'person who shines', that is, *'person who sparkles like a jewel' (another meaning of English shiner is in fact 'diamond; [any] jewel'), and/or from English shiner 'diamond; [any] jewel' (an utterance such as "She's a jewel" could easily spawn one such as "She's a shiner") and may be related to the Australian and New Zealand English slangism shine 'good; likable' (applied to a person, as in "a shine chap").

On page 99 Thomas defined the word kybosh as 'affectation, display, pretence'. Wright thus followed him.

Joseph Wright's dictionary is a great achievement and a useful work in that it spares us the forbidding task of having to locate and plow through many published and unpublished dictionaries, glossaries, similar collections, and primary texts, and in that it contains his and his collaborators' gleanings from spoken English, which might otherwise have been lost. But its limitations should be recognized:

1. Wright's claim that his dictionary is complete (see its subtitle and his preface) is baseless. Indeed, the maker of no dictionary of an open corpus can ever aspire to record everything. Even if the corpus is apparently closed, such as that of Etruscan, texts with hitherto unknown material may come to light.

2. Although Wright did publish requests for help in local periodicals and in that way was able to get in touch with volunteer readers and other correspondents all over the British Isles, to whom he put queries and from whom he received replies as well as their own gleanings (Holder 2004: 255 notes that among those people were "country gentlemen, 
clergy, mill-workers, farmers, students, enthusiasts of all sorts, both scholars and homely folk"), he did not carry out systematic fieldwork, as has for decades been the norm in topolectology.

Rather, just as librarians make union catalogs, Wright made a union dictionary: he drew up a single alphabetical list of all the entries in all the published and unpublished collections of "dialectal" lexemes and meanings he could find, into which he incorporated his and his correspondents' additions and corrections (the sixth volume consists of a second alphabetical list supplementing and correcting the first one). In the days before electronic aids, that was a grueling job and we are grateful to him for carrying it out, but the fact remains that The English Dialect Dictionary, as important and as informative as it is (if used critically), consists of material collected unsystematically and a good portion of it came from people who, as we may infer from Holder's remark just quoted, had no training in linguistics in general or linguistic field methods in particular.

3. Consequently, Wright may have inadvertently perpetuated mistakes; since no systematic fieldwork was done, any number of spatial and temporal labels in the dictionary may be too narrow or too broad; and, because the language has changed, it may now be impossible to discern those mistakes or assign more accurate labels, so that any fieldwork would now yield results different, to a greater or lesser extent, from those it would have yielded in his day (which is no reason, however, not to undertake it).

Here is a possible example involving those labels. As we see from the second and third entries reproduced above, Wright labeled kybosh ${ }^{1}$ and $k y b o s h^{2}$ "Cornwall" (because they appear in two works dealing with the English of that duchy). The proper interpretation of that label wherever it appears in the dictionary is 'used at the time of collection and/or during the time recollected by the consultants in at least certain parts of Cornwall; possibly used before and/or since; possibly not used everywhere in Cornwall; and possibly used elsewhere too' (mutatis mutandis, the same applies to "Ireland," "northern Ireland," and all other spatial labels in the dictionary). Wright's entry "kibosh verb Ireland. "end, finish, put a stop to"" is a case in point: in that sense, the word, as we now know, has also been used in London at least since 25 November $1834 .^{32}$

Which is to say that all the lexemes, constructions, meanings, and pronunciations reported in The English Dialect Dictionary are among the items that would be tested in systematic fieldwork for a massive English linguistic atlas of the British Isles. ${ }^{33}$

In any case, if any of the three usages reported in the dictionary come from Ashkenazic British English, the connection would not be immediate (*“[Western?] Ashkenazic British English > northern Irish English" and *“[Western?] Ashkenazic British English > Cornish English") for at least this reason: the number of Ashkenazic Jews in the northern part of Ireland before 1884 and in Cornwall before 1895 was too small for any variety of local Ashkenazic English to have had any influence on the English of non-Jews there.

Rather, if Ashkenazic British English figures in the etymology of any of the usages reported in those entries, it would be as a non-immediate source, and in one way or another non-Jewish London English would have to figure in the etymology, say, "regional 
Western Yiddish > Western Ashkenazic London English > non-Jewish London English > (?>) non-Jewish Cornish English and/or non-Jewish Northern Irish English". ${ }^{34}$

If any of the usages reported in those three entries derive from British English underworld and/or prison slang, we would assume that certain members of (a) the London underworld and (b) the Cornish and Irish underworlds were in touch (see the first paragraph of subsubsection VII in section C.6 on the requirement that contact between the presumed donor and receiving lects be likely or definite).

Therefore, although we know that the three entries need to be considered in any analysis of our problematic word, we are not sure exactly how they are relevant. For instance, is the semantic similarity between Ashkenazic British English khay bash 'eighteen pence' and Cornish English kybosh 'wages, money' evidence for a genetic connection of some kind between the two words or is that similarity merely a coincidence? If a connection does exist between the two words, the semantic development would be *“"eighteen pence' > 'wages, money'," that is, a broadening of meaning, inasmuch as the descent of the first element of khay bash from a word meaning 'eighteen' is certain.

\section{To conclude (for the time being)}

This article separates out three words from our problematic word: (1) the Ashkenazic British English free collocation khay bash 'eighteen pence', (2) the British English underworld (including prison) slangism kaybash 'sentence of eighteen months in prison', each of which goes back, by a different route, to Western Yiddish, and (3) the clogmakers' term kybosh 'iron bar which, when hot, is used to soften and smooth leather', which has no Jewish connection.

This article has also shed a bit of light on the terra incognitissima that is the Jewish world and a couple of its languages; enriched The Monumental Dictionary of Imaginary Yiddish by a few entries; incinerated an iota of the stinking garbage piously worshiped as the Irrefragable Truth by the linguistically uninformed; implicitly and explicitly suggested certain refinements in etymological method; demonstrated that a thorny etymological problem cannot be fully discussed (let alone solved) in the tiny space available in general dictionaries, the larger space available in popularizations on picturesque word origins, or even in the much larger space available in big etymological dictionaries; implies that a good deal of English vocabulary is still unrecorded (where is The Complete Dictionary of English Clogmaking Terms from the Beginning of the Craft to the Present Day?); and shown that ethics has its place in linguistic research too. ${ }^{35}$

A Yiddish saying goes alts in eynem iz nishdo ba keynem (a pedestrian translation: 'nobody knows everything and can do everything') and Marek Stachowski has issued a call, "Etymologists of the world, unite!" (Studia Etymologica Cracoviensia, vol. 17, 2011, p. 194). To solve all the puzzles of our problematic word, we need the cooperation of people knowledgeable about Ashkenazic British English, British English pronunciation, British Jewry, British underworld (including prison) slang, Dutch thieves' cant, German thieves' cant, ink, Insular Celtic languages, paper, printing, the terminology of cement and of clogmaking (not just in English), watermarks, and Western Yiddish, as well as readers 
of older published and unpublished primary and secondary sources - indeed, of everyone, whether possessing special knowledge or not, who can contribute to the discussion.

\section{Notes}

1. Linguists in general and etymologists in particular have long recognized the possibility of non-monogenesis, that is, the possibility that a linguistic item may have more than one immediate etymon, it often being wiser, in fact, to put one's money on two or more horses ("Word $x$ comes from languages A, B, and/or C") than to stake it all on one ("Word $x$ comes from language A"). In slang, non-monogenesis may be more frequent than in other kinds of vocabulary: Roger "Wescott $(1979,84)$ has made the point that slang is one of the lexical areas where multiple etymology is most remarkable since 'in the absence of a plurality of overlapping or mutually reinforcing source forms, most lexemes would not develop or, having developed, would not persist'“ (Lillo 2000: 149-150). From a later remark by Wescott we gather that a principle of psychoanalysis led him to become sensitive to the possibility of multiple causation: "Accepting the psychoanalytic principle of overdetermination - to wit, that most forms of behavior are products of multiple motivation, I [...]" (Wescott 2000: 243-244). Compare the first paragraph of subsubsection VII in section C.6.

2. For lack of space, little will be said here about pronunciation (see section A.1) and we will concentrate on the earliest known meaning and the earliest known collocation of our problematic word, which during its recorded history have always been its usual meaning and usual collocation.

3. The sketch takes its name from that of Seven Dials, "A region in London, about halfway between Trafalgar Square and the British Museum;--from a Doric pillar bearing a clock with seven dials, and formerly standing in a circular area where seven streets converge" (NID2, s.v. Seven Dials).

4. Since the word occurs nowhere else in the sketch, we cannot be sure whether the hyphen is soft or hard in the imprint of 27 September 1835. In all later lifetime imprints of the sketch having Dickens's authority, it is hard (as we know from the fact that in those imprints it appears in the middle of a line) presumably because the typesetter for the imprint of 1836 (see later in the text), who was presumably working from the imprint of 27 September 1835 rather than from a manuscript (see however the last paragraph of section A.1), took the hyphen to be hard.

5. None of the twelve major repositories of Dickensiana holds the manuscript of the sketch: (1) The Charles Dickens Museum; (2) the Manuscript Department of The British Library; (3) the John Forster Collection (in the Word and Image Department of the National Art Library of the Victoria and Albert Museum); (4) the Townshend Collection (in the Wisbech and Fenland Museum); (5) the Tennyson Research Centre (of the Lincoln Public Library); (6) the Henry W. and Albert A. Berg Collection (in the New York Public Library); (7) the J. Pierpont Morgan Library; (8) the Free Library of Philadelphia; (9) the Henry E. Huntington Library and Art Gallery; (10) the Humanities Research Center (of the University of Texas at Austin); (11) the Houghton Library (of Harvard University); and (12) the Beinecke Rare Book and Manuscript Collection (in the Yale University Library). The manuscript is not in any of the minor repositories either (see Nisbet 1964: 46-47 for a list).

Bernadette Archer, a librarian in the Word \& Image Department of the National Art Library of the Victoria and Albert Museum, wrote me on 21 May 2011 that John Forster's collection of proofsheets of Dickens's works, now held by that department, contains none for "Seven Dials". 
6. Trying to use $O E D$ to determine when 's and $s$ ' arose in English as the possessive endings on nouns and noun phrases (Gold in prep. 2), a subject which students of English spelling seem to have neglected, I have found a number of its quotations faulty in two respects: some the staff copied inaccurately — which is excusable (to err is human) - and some, such as kye-bosk (*kyebosk?), it "predated" (for another example, see note 21) — which is not. Speaking of the preparation of $O E D S$, Robert Burchfield remarked at the end of the project that "I am sure [...] our standards of research and verification of the printed evidence have been consistently higher than those of our predecessors. Victorian standards were lower in such matters; ours is a more pedantic age" (Burchfield 1986: ix). Instead of "more pedantic," he should have written "more professional (though not yet fully professional)".

Paragraph IV in section C.6 notes another deficiency of many quotations in $O E D$, as do later remarks in that section on its earliest quotation for kurbash, and Gold 2005a reports another example of its mistreatment of a word used by Dickens. By inchmeal, however, the dictionary is getting better (a Yiddish saying goes, beser hot kin shier nit 'improvement knows no limit').

7. Here are the genetic possibilities:

A. The custom was adopted from another speech community. Two examples: A.1. In the Jewish world the custom arose among users either of Hebrew or of Jewish Aramaic (spontaneously? as an adoption from one or more non-Jewish groups?) and from them it spread in one way or another to users of other Jewish-letter languages; A.2. speakers of Arabic, as Federico Corriente tells me, got the idea to use alphabetic numerals from speakers of Aramaic.

B. The custom arose spontaneously. That must be the case of the first speech community to use alphabetic numerals but, as we see in the previous paragraph, it is not the case of all of them.

See Malkiel 1968: 358-359, ft. 2, for more on alphabetic numerals.

8. Hence the Yiddish sayings akhtsn iz keminyen khay 'eighteen is equal to life', akhtsn makht khay 'eighteen is equal to life', and akhtsn iz gelebt, nayntsn iz geshtorbn 'desire nothing more than what you need to live modestly' (literally 'eighteen is life, nineteen is death'). No word having a numerical value of nineteen is intended in the last-mentioned saying nor does that number play any special role in the Jewish world, it being used there only because nineteen comes right after eighteen and thus alludes, just in that saying, to a belief that even the slightest deviation from strict frugality spells disaster.

9. In certain varieties of older Yiddish and Ashkenazic Hebrew, /h/,went to /h/, which in certain circumstances dropped out, as in the Yiddish female given name sime and Yiddish verb stem mek- 'efface, erase, rub out' (Vaynraykh 1957/1958). That replacement is presumably irrelevant to the present discussion.

10. Haberman's penultimate sentence should read "In the Jewish world, letters of the Jewish alphabet also have numerical values".

"We have two numbers in the Jewish belief that are lucky numbers. One is 18, and the other is seven. I thought 18 was kind of too high, so I went with seven"“ (Haim Saban, a television executive and creator of Teenage Mutant Ninja Turtles, who gave a record $\$ 7$ million to the Democratic National Committee)" (unsigned, Time, 1 April 2002, p. 22). Eighteen, yes, but seven too?

11. At least one Yiddish numismonyic acronym was definitely coined in the same way as *pash presumably was (tsal 'kreuzer' < Yiddish tseylemer 'idem') and at least four more were coined in almost the same way (pag 'grosz' < Yiddish poylisher groshn 'idem', rakh 'silver rouble' < Yiddish rubl kesef 'idem', rat 'rixdollar' < Yiddish raykhstoler 'idem', and tag 'groschen' < Yiddish taytsher groshn 'idem'). That is, *pash and tsal consist of three phonemes: the first phoneme (= the first consonant) of the full form, the vowel pasekh (cardinal/a/), and the 
second consonant of the full form; and pag, rakh (Hebrew phonology requires the first consonant of kesef to become / $\mathrm{x} /$ in rakh, where it is represented by $\langle\mathrm{kh}\rangle$ in romanization), rat, and tag consist of three phonemes: the first phoneme (= the first consonant) of the full form, cardinal /a/, and the first consonant of the second element of the full form. All those Yiddish numismonyic acronyms have entered Ashkenazic Hebrew.

12. The merger of $/ \mathrm{p} /$ and $/ \mathrm{b} /$ began in certain varieties of High German (it is part of the phenomenon known in German linguistics as der binnenhochdeutsche Konsonantenzusammenfall 'the intra-High-German merger of consonants'), from which it spread to certain varieties of coterritorial Western Yiddish, from which it may have spread (did it?) to certain varieties of coterritorial Ashkenazic Hebrew.

13. One of the reasons for the lack of progress till now in weighing the possibility that our problematic word has a Jewish connection is that almost everyone writing about that possibility has been innocent of all knowledge of Hebrew, of Yiddish, and of Jewish English, as we immediately perceive just from Barrère, Leland, Partridge, Beale, and many others' imaginary "kabas" and "kabbasen," Liberman's imaginary "Hebrew kibosh 'eighteen pence" (see note 22 on those three ghosts), and many others' imaginary "Yiddish kibosh" and "Anglo-Hebraic kibosh" (a pompous glottonymical monstrosity and an imaginary word conceivable only by the Hebrewless, which M.L.R. Breslar launched on page 10 of Notes and Queries of 5 January 1901, the staff of the $O E D$, always unauthoritative in matters Jewish, promptly published in the fascicle ready for the printer by October of that year [KAISER-KYX], and later versions of the dictionary have broadcast to the four corners of the Earth) - to say nothing of other blunders. In brief, almost almost all scribbling about real or imaginary Jewish aspects of the puzzles we are now trying to solve have been speaking ex cathedra ignorantiae — and sometimes doing so, what's more, even after the right information was put before their very eyes. For instance:

A. Way back in 1901, James Platt, Junior, got the ball rolling when, though glottonymically vague and possibly mistaken about pronunciation, he rightly suggested that [Ashkenazic British English? non-Jewish British English?] khay bash 'eighteen pence' may have to be separated out of our problematic word: "kybosh as a slang term for eighteen pence may or may not be connected with" our problematic word (Notes and Queries. A Medium of Communication for Literary Men, General Readers, Etc., ninth series, vol. VII, 6 April 1901, p. 277). What are we to make of his "kybosh [...] eighteen pence"? Was Platt mistaken in writing $\langle\mathrm{k}\rangle$, which unambiguously implies $/ \mathrm{k} /$ ? Or does some variety of British English indeed have a word *kay bash [sic recte] 'eighteen pence'? If so, which one or ones? The existence of that form with that meaning would be primafacie evidence that Ashkenazic British English khay bash 'eighteen pence' did spawn a reflex with $/ \mathrm{k} /$, which could be the missing link (if there was one) discussed in sections C.2 and C.3. See too, in section C.1, the discussion of what Liberman means by "the word kibosh".

B. Twenty-three years later, Herbert Loewe threw out another hint, this one less ambiguous and more clearly reliable than Platt's - "Properly speaking, it [our problematic word (D.L.G.)] should be pronounced 'Khai-Bash,' with the accent on the second syllable. The $k h$ should be sounded as is the ch of Scottish loch" (p. 244) - though he was misleading ("it" should refer only to Ashkenazic British English khay bash) because he believed in the etymological fallacy (here, thinking that since what he took to be the immediate etymon of our problematic word has $/ \mathrm{x} /$, so too should our problematic word) and he did not describe the stress quite accurately (each syllable has primary stress).

However, we easily overlook Loewe's mistakes because towering above them is his mention of $/ \mathrm{x} /$, which should have alerted all the Yiddishless Yiddish "experts," all the Hebrewless Hebrew "experts," and all the Jewish-Englishless Jewish English "experts" trying to come to grips with the 
ancestry of our problematic word that without a reasonable explanation of how $/ \mathrm{x} /$ became $/ \mathrm{k} /$ no etymology involving Yiddish, Hebrew, or Ashkenazic English could be accepted. Naturally, all other sciolists in matters Jewish — including Liberman, who read Loewe 1924 — also ignored Loewe's alert.

c. Sixty-one years later, I hinted at that difference between our problematic word and the Ashkenazic British English one - "It is true that in Ashkenazic British English there was (is?) a word kibosh, but it is pronounced differently from the general English word kibosh in which etymologists have been interested (as in put the kibosh on someone). A detailed article on this word is awaiting publication" (Gold 1985a: 229) — but I disguised Ashkenazic British English khay bash as "kibosh" and did not specify the difference in pronunciation because I did not want anyone to steal my thunder before my "detailed article" (= the comprehensive version of the present one) appeared.

D. Five years later, having realized that seria non leguntur and therefore now certain that nobody would beat me to it, I decided to answer Platt's question explicitly (though I still held back from going into detail): “[...] khay-bosh [...] is not the kibosh in which many have been interested, that of put the kibosh on someone [...]" (Gold 1990c: 153). The hyphen should be a space and the first $\langle 0\rangle$ after it should be $\langle a>$. Mea maxima culpa.

E. Here we are in 2012, twenty-two years later (27 after I first threw out a hint, 111 after Platt asked an important question and at least 138 after discussion of our problematic word began), but no Tom, Dick, or Harry holding forth on the Old Misinformation Highway (print) or the New Misinformation Superhighway (the Internet) has shown any awareness of the pronunciation of Ashkenazic British English khay bash, of regional Western Yiddish khay bash, or of regional Western Ashkenazic Hebrew chay bash, in consequence of which, all those swollen smatterers in matters Jewish and pseudo-Jewish have been unaware of the phonological difficulty confronting anyone trying to connect those words and our problematic one.

Seria non leguntur frivola voracitate devorantur. See $\mathbf{B}$ and $\mathbf{E}$ in note 26 for two more examples.

14. Since the Standardized Yiddish Orthography, on which the Standardized Yiddish Romanization is based, uses no capital letters, capitalization is unjustified. Since the first syllable contains a diphthong rather than two full vowels, 〈ay> is needed instead of <ai>. Since the Standardized Yiddish Romanization follows the Standardized Yiddish Orthography with regard to hyphenation and the latter requires a space rather than a hyphen to separate the two elements of khay bash, that is the correct spelling (I too have been guilty: see paragraph $\mathbf{D}$ in the previous note).

15. Gold in prep. 4 will point out even more extreme oversimplifications, such as "Hebrew shekets > Polish szajgec" instead of "Hebrew sheqets > Jewish French *šegec (or some similar form with /g/) > Western Yiddish sheygets > Central Yiddish sheygets (where <ey> represents /ai/) $>$ Polish szajgec" (the semantic changes are not shown and justification of the etymology is omitted here). Even worse than failure to mention Yiddish because one does not know that it is relevant were the efforts to rewrite history by deliberately ignoring the language or by masking it as "Judeo-German" when one knows well and good that it is relevant or that it is Yiddish and should be so called. Gold 1983a and 1985c expose the deceitful attempts of two unscrupulous "Judeo-Germanists," Werner Weinberg and Josef Stern, who tried to deny even the existence of Western Yiddish (as if someone were to claim that British English or Peninsular Spanish was a figment of the imagination). Fortunately, the culprits were brought to book in print and were among the very Last of the Mohicans.

16. For example, English dictionaries listing Ashkenazic English shul 'synagog' (pronounced Išu:1/) will tell you that the word derives from "Yiddish shul," but since the English word has just 
one pronunciation whereas the Yiddish one has at least then (every one of its three phonemes has at least two realizations), it derives from the Yiddish word as pronounced in just certain varieties of the language. Or, though Polish hucpa and sitwa derive from Yiddish words (respectively khutspe and shutfes) that have the same stressed protovowel (short*/u/), hucpa has stressed /u/ and sitwa has stressed /i/(phonetically [i]) - information which tells us that hucpa comes from Northeastern Yiddish but sitwa does not - and that sitwa comes from Southern Yiddish but hucpa does not (Gold in prep. 4).

17. To this day, the Yiddish name of the street is pey"lamed, whence its Ashkenazic British English name, Pey"Lamed. Pey and lamed are the Yiddish names of two letters of the Jewish alphabet. The first of them represents /p/ here and the second represents $/ 1 /$. Thus, pey"lamed and Pey"Lamed are letterwords alluding to the first phoneme of Petticoat and of Lane.

"In the 19th century the street's colorful name [Petticoat-lane (D.L.G.)] was considered too vulgar, and was changed to Middlesex Street (after a traditional Saxon region of England, and not as a reference to gender ambiguity. [....] In the 19th century, Victorian morés regarded the popular street with a Sunday market on a street named after a lady's undergarment with more than raised eyebrows. In 1830 Petticoat Lane was renamed Middlesex Street and and attempts were made to end the market's long tradition of Sunday operation. [.....]. East Enders still called the market [the Lane]" ("A Walk through the City of London"). Secondary sources give the date of the change from Petticoat Lane to Middlesex Street as "1830," "about 1830," "the 1830s," or "1846". The first or second one is closest to the mark: Elmes 1831 characterizes Middlesex Street as "new". Bridgett Howlett, senior archivist at the London Metropolitan Archives, wrote me on 2 February 2012 that according to the street index of the London County Council dated 1955, Middlesex Street was approved in 1897. Apparently, then, the change was for some sixty-seven years unofficial.

18. In Montefiore 1846, kamin, which has final stress, is spelled commean, which suggests that the pronunciation which the author knew for the word was *[kə'mi:n].

19. Since Modern English caliph continues Middle English caliphe califfe, which comes from Middle French caliphe califfe, which comes from Medieval Latin calipha, which comes from Arabic xaliffa, replacement of /x/ by / $/$ / occurred in Medieval Latin, not in French or English. More English words like caliph in that $/ \mathrm{x} /$ occurs in a pre-English stage of their etymologies are caviar, Micah, Michael, Mocha, and mocha.

Examples of " $/ \mathrm{x} /$ or $/ \mathrm{h} />/ \mathrm{k} /$ " in non-English words that do not figure in the etymologies of any English words are French Cham 'Ham', Italian Cecov 'Chekhov', Lingua Franca cafana 'wardrobe' (< Arabic hezāna [Schuchardt 1909]), and Portuguese moka 'mocha'.

In Catalan (which does not have */x/), Spanish /x/ regularly becomes /k/ (Badia i Margarit 1962, vol. I, §61.3, p. 103). In Latvian (which does not have $* / x /$ either), Russian /x/ always becomes $/ \mathrm{k} /$.

Gold ms. 1 will give more examples of such replacements in the world's languages. They occur if people take the velarity of $/ \mathrm{x} /$ and pharyngality of $/ \mathrm{h} /$, not their fricativeness, to be the distinctive feature of those two sounds. In contrast, people who replace $/ \mathrm{x} /$ or $/ \mathrm{h} / \mathrm{by} / \mathrm{h} /$ (see earlier in the text on the English reflexes of Mexican Spanish juzgado, Yiddish khale, and Yiddish khutspe) take their fricativeness, not the velarity of the first sound or the phyaryngality of the second one, to be their distinctive feature.

English does have instances of $/ \mathrm{k} /$ in replacement of non-English $/ \mathrm{x} /$, but not, so far as I know, word-initially (except in kamin): for instance, the Dutch place name Utrecht contains / $/$ (represented by <ch>) and its English reflex, Utrecht, has /k/ (likewise, New Utrecht, the English name of a neighborhood in Kings County, New York, which is a translation of Nieuw Utrecht, the Dutch name of the village in New Netherland which eventually became that neighborhood, has 
/k/); and German syllable-final / $\mathrm{x} /$ regularly becomes $/ \mathrm{k} /$ in the English of people outside the range of German phonological influence (as in the German names Bach, Bachrach, Auerbach, and Offenbach).

20. In non-Jewish German, Yiddish word-initial / $\mathrm{x} /$ has also been replaced by $/ \mathrm{h} /$, as in Haber and Heniefes (respectively from Western Yiddish khaver and khenifes). If / $\mathrm{x} /$ in a Yiddish word has gone to both /x/ and /h/ in its German reflex, the result is doublets (such as Cabber Kabber and Haber). See the previous note on distinctive features.

21. The originally British English underworld cryptolectalism nicks nix 'nothing' is presumably evidence of contact between (a) the English- and (b) the Dutch-, High-German-, and/or Low-German-speaking underworlds.

$O E D$, following its unprofessional practice of "predating" mentioned in section A.3 (see too note 6), assigns the date "1789" to what it offers as its earliest quotation for English nicks 'nothing' even though it took the passage, as the dictionary frankly states, from an imprint to which it assigns the date " $c$ 1800". Therefore, unless the word is verified as appearing in the imprint of 1789 , we should date it to "about 1800 ," but since $O E D$ took the latter date from the catalog record in The British Library, even that rewording is unsatisfactory: read "about 1800 according to The British Library (on what evidence?)". See note 29 for another example of a guessed date.

The passage from the imprint assigned the date "about 1800" reads as follows: "How they have brought a German word into cant I do not know, but nicks means nothing in the cant language". Parker's characterization of nicks as cant motivates my description of nicks $\sim$ nix as an "originally British English underworld cryptolectalism". His use of the word German should not be taken as proof that the immediate source of English nicks nix is (Low? High? both High and Low?) German, for it was only a guess on the part of a nonlinguist. Given the scantiness of the evidence, this etymology is the prudent one: < Dutch niks 'nothing', informal High German nix 'idem', and/or Plattduetsch nix. Also, since the glottonym German (as well as the glottonym Dutch) has more than one meaning, we are not even sure what he meant by it - all the more reason to be careful.

The etymology for nicks nix 'nothing' in $O E D$ is "colloquial Du. and G. nix, for (nichs) nichts," but we are not told how it was determined. As just suggested, it is better to err on the side of caution. The wording "for (nichs) nichts," whatever it means, is not professional.

22. John Neville Gosling (1905-1977) was a founding member of the New Scotland Yard Squad, the purpose of which was to gather intelligence, chiefly in the East End of London. Eric Partridge reported kibosh 'sentence of eighteen months in prison' in Gosling 1959:

"Kibosh, v., and as n. in put the kibosh on, has as its main sense 'to ruin, spoil.' The latest OED Sup., 1976, offers no explanation for the word's derivation; but the very oddity and exotic feel of it have prompted several etymologies, the most plausible being B. \& L., 'ex Yiddish kabas, kabbasen, to suppress'. Julian Franklyn (author of The Cockney, A Dictionary of Rhyming Slang, Shield and Crest) proposes a quite different origin: the heraldic caboshed (or caboshed or cabossed or cabaged or...) — see the OED — and Scots hunting caboche or cabage or cabbage, to cut off a deer's head close behind the horns. (Cf. cabbage, n., 1.) Yet another theory is suggested in G. Drepperd, American Antiques (glossary), 1944: 'Kibosh: blowing of cement or plaster on sculptured or wooden forms; hence the old phrase 'to put the kibosh on', meaning to change the shape and form' (Douglas Leechman, 1977). E.P. considered that 'both the Franklyn and the Drepperd theories are rather too technical for an expression so lowly'-and Drepperd's may well be a derivation rather than the origin. The earliest instance discovered by E.P. dates from 1836: Dickens, in Boz, "“Hooroar," ejaculates a pot-boy..., "put the kye-bosh on her, Mary!" " At kye, in the 1st ed. of this Dict., E.P. noted 'Eighteenpence: costermongers': from ca. 1860. Abbr. Yiddish 
kye, $18+$ bosh, pence.' If this is correct, it may be that this arbitrary sum is the answer: cf. the later 'give him a fourpenny one', which would fit the Dickens' context with no change in sense at all. The '18' crops up again in the sense of kibosh used by John Gosling in The Ghost Sequel, 1959: a prison sentence of 18 months. Other, later, meanings were $(a)$ Nonsense; anything valueless [?the 18 pence again]; it is recorded by Hotten, 2nd ed., 1860, and occurs in Punch, 3 Jan. 1885, "Appy New Year, if you care for the kibosh, old chappie'. E.P. sees this as a blend of bosh 1 and 2, trash or nonsense, and the already extant kibosh, and adds 'Occ. kiboshery'. (b) Fashion; the correct thing: low: from ca. 1888. As in 'That's the proper kibosh'. (c) In put (a person) on the kibosh, to calumniate: recorded by Manchon, 1923. Contrast (d) put the kibosh on (a person or affair), as in the Boz quot'n above, and in the very popular WW1 c.p. 'We'll put the kibosh on the Kaiser'-for which the word could have been tailor-made! $E D D$ records the v. (which E.P. glosses additionally as 'check; bewilder; knock out (lit. and fig.)'), with the note 'Irish', and date 1884. A Cockney var., recorded by Baumann, 1887, was kyebosk.

"This note compiled, 1980, by P.B. from existing entries in the 7th ed. of this Dict., and incorporating E.P.'s additional material (Leechman's contribution). Further theories and conjectures may be found, very amusingly presented, in Leo Rosten, The Joys of Yiddish, pub'd in USA, 1968, in UK, 1970. Rosten is doubtful about derivation from Yiddish" (Partridge 1989: 1385, where B. \& L. and E.P. respectively mean 'Barrère and Leland 1889-1890' and 'Eric Partridge').

The comprehensive version of the present article will dissect those misconceived musings one by one. Here we will note just this:

1. Eric Partridge "discovered" the Dickens quotation of 1836 ? Didn't he merely look up the word kibosh in OED? Even had he found the one of 27 September 1835, the event would have been nothing to write home about because the first place of publication of "Seven Dials" has long been known in Dickensian circles. What a pity there's no Nobel Prize for Linguistic Discoveries.

2. Yiddish *"kye"? What word is that? What is the evidence for it?

3. Yiddish *"bosh"? What word is that? What is the evidence for it? I too have been guilty of misromanization (see paragraph $\mathbf{D}$ in note 13). Mea maxima culpa.

"the most plausible being B. \& L".? What could the linguisticless and the Yiddishless Paul Beale, a soldier, have possibly known about Yiddish to authorize him to make a mockery of standards of evidence and hand down a judgment about the linguisticless and the Yiddishless Eric Partridge's making a mockery of standards of evidence and handing down a judgment about the linguisticless and the Yiddishless Barrère and the linguisticless and the Yiddishless Leland's fantasies — "kabas, kabbasen, to suppress" - are "the most plausible" etymons of our problematic word? For another example of Beale's naivete in matters linguistic in general and Jewish linguistic in particular, see Gold 1989b. Partridge and Beale could not have drafted an etymology per artem even if you had held a gun to their heads. As Voltaire is alleged to have remarked, 'Etymology is the science where the consonants count for very little and the vowels for nothing at all.'

4. "Rosten is doubtful"? Leo Calvin Rosten was incapable of even speaking or writing a Yiddish sentence, even understanding a spoken or a written Yiddish sentence, even if you had held a gun to his head. All the serious reviews of The Joys of Yiddish were damning; only the Yiddishless wrote otherwise. When challenged to debate his critics (in Yiddish, of course), he tried to wiggle his way out (in English, of course): "prior commitments". Later he tried to wiggle his way out again by claiming that his book was not about Yiddish but about English words of Yiddish origin. A drowning man will catch at a straw. 
In the eyes of the hordes of ignoramuses pontificating on etymology, our science consists of nothing more than finding a similar-looking word, whether real or imaginary, proclaiming it the etymon, and then rushing on to another blunder. Partridge's and Beale's putting their worthless stamp of approval on Barrère and Leland's imaginary *"kabas" and imaginary *"kabbasen" shows that the only "rule" of etymology they knew was "if item $x$ looks or sounds like item $y, x$ must be derived from $y$, even if $y$ is a fantasy".

To set the record straight on those two ghosts:

4.A. Every Yiddish infinitive verb (note "to" in "to suppress" above) ends in one of the four allomorphs of the Yiddish infinitive ending: - $n$ (as in derhayntikn 'bring up to date, update'), -en (as in keyflen 'multiply'), -nen (as in ganvenen 'rob, steal'), and -e-en (as in paskenen 'decide, judge, rule [that is, hand down a legal decision]'). "Kabas" could thus not be an infinitive (Yiddish, by the way, has no trochees with /a/ in the second syllable, so that *"kabas," if it existed, would have to be finally stressed).

4.B. "Kabbasen" does have what might at first glance look like an allomorph of the Yiddish infinitive ending, but on second glance, we realize it does not, for if a Yiddish infinitive ends in $/ \mathrm{sen} /$, its stem must be of immediate Slavic origin, as in the Eastern Yiddish verb pasen 'tend [a grazing animal or animals]', the stem of which is pase-, which comes from the present-tense stem, as pronounced in mazurzenie, of Polish paść 'idem' (contrast the Yiddish verb pasn 'be appropriate, be proper', which, being of medieval German, hence non-Slavic, origin, has no /e/), yet "kabbase-" could not be from any Slavic (or any other...) language.

4.C. Since Yiddish has no geminate phonemes, "bb" is possible only in a morphophonemic transcription and then only across a morpheme boundary, so that "kabbasen" would have to consist of at least three morphemes ("kab," "bas," and "-en"). Only -en (see paragraph 4.A above) and the musical term bas 'bass, basso' exist, but they could not combine as *"basen" (it would have to be *"basn") - and what would such a verb (with kab- '?') mean? Would it be a musical term?

4.D. The score so far: only -en and the semantically irrelevant bas in "kabas, kabbasen" exist, but they are not compatible.

4.E. Let's stop playing serious with Barrère, Leland, Partridge, and Beale's illusions and selfdelusions (I've violated the Yiddish dictum af a nar iz kin peyresh nit tsu makhn 'you don't write a commentary on a fool') and get to the point: no amount of reasonable reromanization of those two fantasies - which together with "Hebrew kibosh," "Yiddish kibosh," "Anglo-Hebraic kibosh," the imaginary words reported in Gold 2009e and 1989e, and many others have won entry into the prestigious $M D I Y$ - would yield any Yiddish verb meaning "“to suppress" " or any other Yiddish word which even by an excruciatingly painful stretch of the imagination could be relevant to the problem at hand or yield even any Yiddish words at all. The only Yiddish verb which even faintly resembles those two ghosts is the periphrastic verb goyver zayn 'overcome, vanquish, surmount, conquer', which is too far in form from our problematic word to be relevant (to boot, goyver zayn has no reflex in Ashkenazic English, which, as noted in section C.1, is the indispensable link between Yiddish and non-Jewish English unless some other etymological chain is proposed say, "Yiddish > German thieves' cant > British thieves' cant > British slang" [see section C.4], which is impossible here), to say nothing of the fact that a verb containing Yiddish bas 'bass, basso' would have to be a musical term.

4.F. Fantasies too have their etymologies: someone possessing a baby flea's thimbleful of Hebrew and far less Yiddish must have learned of the real HEBREW verb kavash, among the meanings of which are 1. 'conquer, subdue'. 2, 'subjugate, enslave'. 3. 'suppress, restrain', and, with a defective magic wand, turned it into the imaginary YIDDISH words *"kabas" and *"kabbasen". 
Having cremated "kabas" and "kabbasen," we will now incinerate another fantasy put into mass circulation by those innocent of any Jewish knowledge yet with pretensions of being able to dissert on Jewish or possibly Jewish aspects of our problematic word. Liberman 2010 matter-offactly informs us that "in Hebrew kibosh 'eighteen pence' the first vowel is also short," which is eleven words of nonsense:

A. No Hebrew word may reasonably be romanized "kibosh" (see note 13). The closest we can come to anything Hebrew meaning 'eighteen pence' is British (originally Western) Ashkenazic Hebrew chay bash 'eighteen pence'.

B. What does "short" mean and what is the evidence for the shortness of the first vowel of "Hebrew kibosh"? And in what variety of Hebrew is the vowel short?

c. In fact, since Hebrew (or Yiddish or Ashkenazic English) has no such word as *"kibosh," meaning *'eighteen pence' or anything else, nobody could know anything about that imaginary word other than that it is a fantasy and, maybe, explain who concocted it and how.

D. The closest we can come in form and meaning to "Hebrew kibosh "eighteen pence" is British Ashkenazic Hebrew chay bash 'eighteen pence', which could not be an etymon of our problematic word.

The comprehensive version of the present article will review the rest of Liberman 2010. For the moment, we will say only that its author, who gives every evidence of possessing no Jewish English, no Yiddish, no Hebrew, no broad and deep knowledge of the Jewish world, was bound to get into water over his head when he tried to deal not only with Jewish aspects of our problematic word but also with two other etymologically problematic English words squarely of Jewish interest, the ethnophaulisms kike and sheeny (Gold in prep. 3). Even in so elementary a procedure as romanizing a Yiddish or a Hebrew word correctly, he failed every time he tried - to say nothing of other serious mistakes in what amounts to almost Partridgean treatments. In contrast, when he sticks to what his training has prepared him for - the etymologies of Old and Middle English words of Germanic origin - you sense immediately that he commands the data, he commands the research literature, he is at home in the field, he is reliable, and he contributes to the storehouse of knowledge.

Grasp all, lose all. Know thyself. Linguistic investigations, no less than any other kind of human behavior, are subject to a code of ethics.

23. In January 2012 Wolfgang Mieder checked the four dictionaries of Rotwelsch held by the Bailey/Howe Library of the University of Vermont for *kai 'eighteen', *kei 'idem', *Basch 'pfennig; pfennigs', *Pasch 'idem', and their four possible combinations ('eighteen pfennigs') but found nothing (in light of note 20, I now see that I should have also asked him to check for *hai 'eighteen' or *hei 'idem' and to check Avé-Lallemant 1858-1862). What conclusion to draw from their absence is not clear. If no such forms have ever existed in Rotwelsch, my etymology must be discarded. If at least one form meaning *'eighteen' and at least one meaning *'pfennig' have existed, a free collocation meaning *'eighteen pfennigs' must have been used many times. If taken to the United Kingdom, that collocation could have been adopted into English as an underworld cryptolectalism meaning *'eighteen pence' (see the fifth paragraph of section B.2). Might those dictionaries of Rotwelsch be incomplete?

24. The word arbitrary is used here in the sense that William Dwight Whitney and, following him, Ferdinand de Saussure intended when they stated that linguistic signs are arbitrary, that is, no correlation exists between their form and their meaning or, expressed in a different way, signs are not iconic (they were presumably excluding from consideration instances of onomatopoeia and maybe they were unaware of phonesthemes). For example, the literal meaning of the monomorphemic English words cloth and table are arbitrary, for theoretically they could have any 
meaning, whereas the literal meaning of the bimorphemic word tablecloth is less arbitrary because it is a function of the meaning of its constituent morphemes, as a result of which its meaning is likely to range less than those of cloth and table. Indeed, CDC, NID2, NID3, and OED have appreciably more definitions for table and for cloth than for tablecloth. Thus, the more arbitrary a lexeme is, the looser the connection between its form and meaning, and the likelier it is to acquire more meanings.

25. Is it valid to reconstruct a collocation or would doing so be begging the question?

26. Reflexes may be innovative at least in these ways:

A. Pronunciation: Eastern Yiddish shmok and its immediate English reflex, shmok, do not have the same vowel (Gold 1982c and 1983d).

B. Word class: Eastern Yiddish di untershte shure is a noun phrase, whereas its immediate English reflex, the bottom line, has, with omission of the definite article, come to be used as an adjective too, as in "[...] the bottom-line results are unacceptable [...]" (someone quoted, 10-am news, WQXR-FM, New York City, 22 July 2008) and "The CFO-CIO Dynamic - Collaborating to Add Bottom-Line Value" ("Join Us for the Ninth Annual Los Angeles Executive Roundtable," advertizement, The New York Times, 11 May 2010, p. D12).

Steinmetz 1976 and Gold 1981b report the Eastern Yiddish etymon of the bottom line, but no dictionary etymologizes that three-word lexeme (see the last paragraph of note 13). Since the absence of an etymology for a lexeme or a meaning in an English dictionary with etymologies implies that it arose in English under no alloglottal influence, every dictionary with etymologies that lists the bottom line misetymologizes it.

c. Morphology: The respective plurals of Yiddish beygl and mentsh are beygl and mentshn whereas those of their immediate English reflexes are respectively beygls and mentshes, as we see here:

"The bagel, a form of Jewish baked goods sometimes described as a doughnut with rigor mortis, will not disappear from New York tables [...]. Bagels are regarded as a necessity in some homes - especially on Sunday morning" (unsigned 1956).

"[...] the Jewish Alcoholic Pride Day march, a million mensches strong" (McCall 1997). The Jewish Alcoholic Pride Day march is the author's name of one of the events he tongue-in-cheek predicted for the future (it alludes to the Million-Man March, an event having no Jewish connection that took place on 16 October 1995, in all likelihood with fewer than a million men).

"They fool you into thinking that they are devoted, but then prove otherwise. A mensch can be exciting in his own right because of his depth of character" (Newman 2006, quoted here after Metro, New York, 27 August 2006, p. 15, where it is explained that the book deals with "why women often look for the exciting guy and not a nice mensch. She advises that mensches make the best marriage material"). Since the Eastern Ashkenazic English word in question comes immediately not from German Mensch but from Eastern Yiddish mentsh (in the history of which figure German and Polish), it should be spelled mentsh.

D. Syntax (including collocational possibilities): Certain English instances of topicalization (emphasis of a direct object by putting it at the beginning of a sentence) are of immediate Eastern Yiddish origin (topicalization is so frequent in Eastern Yiddish when compared to general English that it is also called $Y$-fronting, the letter $Y$ standing for Yiddish). For instance, "We weren't always old and conservative. We used to be young and conservative. Trendsetters, we're not" (the beginning of an advertizement placed by the New York Life Insurance Company, Newsweek, 27 July 1992, p. 10) and "Review: Three pop tenors: Pavarotti they ain't" (the title of Rob Kent's negative review, Daily News, New York, 28 September 2007, p. B25). 
Y-fronting in Yiddish requires the inflected verb to be the second sentence unit whereas Yfronting in English, whether of Yiddish origin or not, requires the inflected verb to be the third unit, as we see in this pair of equivalents: "Pavarotti they ain't" (= predicate noun + subject + verb phrase $[=$ verb + negative adverb $])=$ Eastern Yiddish "ka pavrotes zenen zey nisht," word-forword 'no Pavarottis are they not' (= predicate noun phrase [= negative article + noun] + verb + subject + negative adverb).

E. Meaning: Yiddish khutspe 'brazen impudence, shameless audacity, unmitigated effrontery' denotes only behavior or a disposition held to be undesirable or inappropriate whereas the English reflex of that word, khutspe, has two meanings, namely, one identical to that of its Yiddish etymon and the other denoting boldness or nerve deemed to be desirable or appropriate (Gold 1986a: 104 explains how the second meaning came about). Here is an example of the use of the English word to designate something desirable: "We can only hope that that young, ambitious City Councilman Adam Clayton Powell 4th has half the chutzpah of his late pop, Adam Clayton Powell Jr., because he has two enemies coming at him faster than speeding blanks, more powerful than the IRT" (Linda Stasi, with A.J. Benza and Michael Lewittes, "Hot Copy," Daily News, New York, 14 September 1993, p. 17).

Gold 1986a: 104 reports the innovative meaning of the English word khutspe and examples abound in the written and spoken language, but no dictionary lists it (see the last paragraph of note 13).

27. English does have the collocation put [...] on [...] where the direct object designates a sum of money, but it is irrelevant here because its meaning is 'venture [money] on [...]' (as in "They put ten dollars on that horse and won a hundred"), not *'bid [...] for [...]' or *'sentence [...] to [...]', and because it does not contain the definite article.

28. An etymology is not complete if it does not etymologize pronunciations that the diachronic phonology of the receiving language cannot predict. Here are two instances of a predictable change (which also exemplify convergence [see note 30]): because "/ai/ > /a: $/$ " is an ongoing regular change in the English of the southeastern United States (as in ice, like, and write) and a regular change that ran its course in Yiddish protovowel 34 in Central Yiddish (as in haynt 'today' and shayle 1. 'question'. 2. 'question about Jewish religious law'), the etymologies of the morphemes or the words exhibiting that change do not need to explain it - nor should they, because the proper place to do so is in a description of the protovowel in question and its realizations.

In contrast, because the pronunciations of the English word kurbash are not predictable from its immediate etymons, each of them must be etymologized separately, which is not an easy task (and may in fact not be fully accomplishable). The comprehensive version of the present article will set forth the problems and attempt to solve them (no English dictionary comes even close to success). Marek Stachowski has sent me his etymology of the Turkish etymon of the English word, which reads as follows:

"kırbaç presumably = Turkish verb stem kir- 1. 'break, split'. 2. 'destroy' + the Turkish nounforming suffix $-b a c$ (though $/ \mathrm{b} /$ is unexpected here because that suffix, which is added to verb stems, usually takes the form -maç and we therefore expect *kıaç, as in bulamaç 'a kind of thick soup made with flour' [= bula-1. 'to roll in flour; to bedaub'. 2. 'to stir' + -maç], whereas the allomorph $-b a c$ cotherwise occurs only after stem-final $/ \mathrm{m} /[<$ the passivizing morpheme $-n-]$, as in dolambaç 'winding [in a road]' $[<*$ dolanbaç (= dola-n- 'to meander; to be wound [literally 'to be wrapped'] < dola - 'to wind [literally 'to wrap'])]). Examples of the cluster /nb/ pronounced [mb] are İstanbul 'Istanbul', penbe pembe 'pink, rosy', and menba memba 'source, spring' (all those words have [mb] regardless of their spelling)". 
29. Ferguson surmizes in his bibliography that the text of the broadside was written in London in 1830 or thereabouts in response to the agitation over the Reform Bill that would be passed in 1832. However, at least till specialists examine its ink, paper, printing, and any watermarks it may have, we should withhold judgment on its place and date of publication. For the time being, therefore, the broadside is evidence only for kibosh in an undetermined sense, it does not allow us to antedate our problematic word, and we do not know whether it will ever be valuable etymologically. See note 21 for another example of a guessed date.

Richard Walker, of The British Library, wrote me on 17 January 2012 that no entry for the broadside appears in the catalog of that library, the English Short Title Catalogue, or COPAC National, Academic, and Specialist Catalogue of the United Kingdom and Ireland. The copy in the National Library of Australia may therefore be the only surviving one. It does seem to be the only known one.

30. Here is an example of how transmission is an important consideration in etymological research. The parlor and party game most often called telephone in American English and Chinese whispers in British English is called 'broken telephone' at least by speakers of Bulgarian (razvalen telefon), Finnish (rikkinäienen puhelin), Israeli Hebrew (telefon shavur), and Ukrainian (zlamanij telefon), as well as by certain speakers of English (broken telephone) and Spanish (teléfono roto). Because of the spatial proximity of Bulgarian and Ukrainian, we assume that the names in those two languages may be genetically related (but, if so, we lack information to decide whether Bulgarian has influenced Ukrainian, vice versa, or both names go back, whether immediately and/or non-immediately, to a third language). Because of the moderate influence of British English on Israeli Hebrew, we suppose that the Hebrew name may be translated from the British English one. However, in no case are we sure of any genetic relationship between any two names because they may have arisen independently of each other (see note 28 on convergence), in any number of ways (each could be a spontaneous coinage; one could be a spontaneous coinage and the other a translation of a name in a third language; if one is a translation of a name in a third language and the other a translation of a name in a fourth language, they are or are not ultimately related; and so on). Thus, evaluating a suggested etymology requires, among other things, consideration of range of influence, which is to say, consideration of the route or routes by which the etymon or etymons have been transmitted from the donor language or languages to the receiving one or ones, and a recognition that indisputable solutions may not be possible, so that it is often wiser to offer nothing more than a number of possibilities: "possibly from $x, y$, and/or $z$ ". In the present article, and/or is used liberally.

31. If the dates of the quotations for kurbash in $O E D$ are any guide, the English political term government by kurbash 'the oppression of a people by the constant abuse of the kurbash to maintain authority, to collect taxes, or to pervert justice' (unsigned 1911) probably dates to the Victorian Era. OED should list it.

32. Consequently, to be systematic, Wright would have had to test each lexeme and each meaning he listed in his dictionary on a sample of anglophones from throughout the British Isles - a Herculean task, which has never been carried out. It is still feasible, though today it would not necessarily yield the same results as in his day.

In connection with kybosh in Cornwall, we wonder whether Courtney and Couch 1880 has any further information.

33. For many years the unfortunate result of unsystematic fieldwork could be seen in edition after edition of the dictionary of the Royal Spanish Academy, which feeds in part on material submitted by the Spanish language academies outside Spain: if, say, the Panamanian academy recommended that a certain Panamanian usage be listed and the staff in Madrid knew it for no 
other place, it was put into the dictionary and labeled a Panamanianism, even though it might also be used outside Panama (no attempt was made to find out), the result being a spatial label that was too narrow. My understanding is that now, when an academy outside Spain recommends local usages for inclusion in the dictionary, the other academies are queried before spatial labels are chosen (though usages universal in Spain and found only there are still unlabeled...).

A possible drawback of The English Dialect Dictionary is that because a sharp definition of "dialect" does not exist, collector A may have recorded a linguistic item for place A because she considered it "dialectal" and it truly is, whereas collector B knew the item for place B but did not record it because, wrongly, she did not consider it "dialectal". As has more than once been remarked in topolectological circles (I first heard this quip in the late 1960s but it must be older), certain isoglosses in certain linguistic atlases may reflect not differences in linguistic usage but differences between fieldworkers.

34. Non-Jewish London English should be included in the etymological chain for this reason: since more Ashkenazic Jews have lived in that city than in any other place [all other places?] in the British Isles, Ashkenazic English influence on British English is likeliest there. If non-Jewish London English is not included, proving the etymology will be harder and maybe impossible.

In the mid and late nineteenth century, Whitechapel (see the sentence, in section C.1 to which note 17 is attached), in addition to its large Ashkenazic Jewish population, had an appreciable Irish population. Therefore, *'regional Western Yiddish > Western Ashkenazic London English > London Irish English > Northern Irish English" is not impossible.

35. The vehemence of my criticism is always commensurate with the outrageousness of the lack of relevant training. Mind you, I speak of lack of relevant training, not mistakes, for even the best researchers make mistakes, possibly serious ones (Yiddish saying: der lamdn, az er grayzt, grayzt er harb 'when scholars err, their errors are serious').

Consider, for example, Korach with Mordock 2002 and 2008, which, wisely not claiming to offer anything new to scholarship, do not pass muster even as accurate popularizations (their treatment of our problematic word, to be dissected in the comprehensive version of the present article, is nothing more than a concatenation of mistakes old and new). Admirably candid confessions on the back cover reveal the compilers' "relevant" credentials:

"Myron Korach was born in 1901 and received a law degree from Case Western Reserve University Law School in 1929. While he attended law school, Korach taught immigrants to read and write, his first experience with their difficulties with idioms. He continues to play contract bridge and fit in the occasional round of golf" (2002). "Myron Korach was born in 1901 and received a law degree from Case Western Reserve University Law School in 1929. He lived in Florida" (2008).

"John Mordock, a psychologist by training, has published six books and numerous articles in professional journals. An avid fly fisherman, he has also published articles in outdoor magazines" (2002). "John Mordock, a psychologist by training, has published several books and articles in professional journals. He lives in New York" (2008).

We are either astonished (if naive) or not astonished (if experienced) to learn that "Using public library archives, both in his home state and during his travels, [Korach] found the histories primarily in old magazine articles and books. The British magazine Puck was the source for many. Others were found in old novels or in books on mercantile, maritime, and military history. Some of the histories could be particularly substantiated by examining general references, such as the twenty-two-thousand-page Oxford English Dictionary but many could not" (Korach 2002: ix) and that when he made his "his initial foray into researching the origins of idioms [he] was assisted by a colleague and close friend[,] Henry Hertz, a practicing attorney" (Korach 2008: v). 
Let's see how expertly $O E D$ was "examined":

The idiom rob Peter to pay Paul, the compilers inform us, originated in an incident that occurred in 1750 (pp. 67-68). OED has quotations for one or another of its three variants (rob Peter to clothe Paul rob Peter to give to Paul rob Peter to pay Paul) dating to about 1380 , about 1440, 1515, 1546, 1596, between 1657 and 1692, and 1737. Pursuant to section C.5 ("Navigating without a Compass") of the present article, the compilers' explanation is hereby tossed into the fire. Case closed! No appeals!

Still navigating without a compass, the compilers inform us that the idiom neither rime nor reason was coined by Edmund Spenser (pp. 172-173). The earliest quotation in $O E D$ in which rime and reason are coupled is from about 1430 and its earliest with a negative word is dated 1530 (without rime or reason). Spenser was born in 1552 or thereabouts. Pursuant to section C.5...

The idiom silk stocking applied to a person, the compilers inform us, was first used in 1876: "John Morrissey, a retired New York prizefighter, stepped from the prize ring into the political ring. Initially he was quite successful. Then, in 1876 [...]. Morrissey's stunt worked, and, inspired by this dramatic coup, the public nicknamed the defeated power brokers 'silk stockings" (pp. 8283). All that may be true (is it?), but silk stocking applied to a person did not originate with Morrissey or in 1876: the first quotation in $O E D$ showing application of that lexeme to a person is dated 1840. Pursuant to section...

Not revealing the date of the alleged unveiling or the source of their "information," the compilers tell us that "The term 'lobbying' [...] originated in England shortly after the British Parliament's building was unveiled" (p. 83). The earliest quotation in $O E D$ for lobby in the political sense is dated 1808, it is American, and it refers to the United States. Not proven! Case closed! Adduce pre-1808 evidence from the United Kingdom and your case will be reheard!

And on and on and on go the compilers' fluffs and muffs and stumbles and fumbles and boggles and bobbles. In disciplines such as nuclear physics and organic chemistry, nobody could get into print with such foolishness, but when it comes to human language, anyone ignorant even of the ABC's of linguistics can appoint himself an expert (that's not so sexist a remark as you may think - almost all the culprits are men) and naive publishers flood the market with junk (because it sells). Foray — what a revealing word.

If ever you require the services of someone who can do the work of one psychologist and two attorneys, is an ace at copying psychological advice and legal decisions from sources as reliable and professionally recognized as old novels and the humor magazine Puck, doesn't know how to use The Oxford Dictionary of Psychology or The Oxford Dictionary of Law, is an expert on contract bridge, fly fishing, golf, and the outdoors (where, of course, he navigates without a compass), and will instantly give you the queasy feeling that he hasn't the foggiest notion of what he's supposed to be doing, I'm your man, for I have sterling credentials in linguistics!

\section{References}

Ackroyd, Peter (1990): Dickens. London: Sinclair-Stevenson Limited. New York: HarperCollins Publishers.

Antes, John (1801): Observations on the Manners and Customs of The Egyptians, the OverFlowing of the Nile and Its Effects; With Remarks on the Plague, and Other Subjects. Dublin: "Printed by J. Jones" [reprint: London, "Printed for J. Stockdale," 1802]. 
Antonsen, Elmer. H. (2002): Runes and Germanic Linguistics [= Trends in Linguistics, Studies and Monographs 140, Werner Winter and Walter Bisang, eds.]. Berlin and New York: Mouton de Gruyter.

Atkinson, Damian, ed. (2003): The Correspondence of John Stephen Farmer and W.E. Henley on Their Slang Dictionary, 1890-1904. Lewiston, New York: Edwin Mellen Press.

Avé-Lallemant, Friedrich Christian Benedikt (1858-1862): Das Deutsche Gaunerthum in seiner social-politischen, literarischen und linguistischen Ausbildung zu seinem heutigen Bestande. 4 vols. Leipzig. F. A. Brockhaus [revised edition, Munich and Berlin, 2 vols, 1914; reprinted, Wiesbaden, Fourier, 1998; all unseen].

"A Walk through the City of London". Website of the City of London [accessed on 5 February 2012].

Badia i Margarit, Antoni M. (1962): Gramática catalana. 2 vols. Madrid: Gredos.

Bailey, Richard W. (2004): Review of Atkinson 2004. Dictionaries: Journal of the Dictionary Society of North America 25: 175-179.

Barnhart, Robert K., and Sol Steinmetz (1988): The Barnhart Dictionary of Etymology. New York: The H.W. Wilson Company.

Barrère, Albert, and Charles G. Leland (1889-1890): A Dictionary of Slang, Jargon, and Cant, Embracing English, American, and Anglo-Indian Slang, Pidgin English, Tinkers' Jargon, and Other Irregular Phraseology. [Edinburgh] "Printed for subscribers only at the Ballantyne Press".

Baumann, Heinrich (1887): Londonismen (Slang und Cant 1887) / Alphabetisch geordnete Sammlung der eigenartigen Ausdrucksweisen der Londoner Volkssprache sowie der üblichsten Gauner-, Matrosen-, Sport- und Zunft-Ausdrücke; mit einer geschichtlichen Einleitung und Musterstücken; ein Supplement zu allen Englisch-Deutschen Wörterbüchern. Berlin-Schöneberg: Langenscheidtsche Verlagsbuchhandlung (Prof. G. Langenscheidt).

Baumann, H[einrich] (1902): Londonismen (Slang und Cant) Wörterbuch der Londoner Volkssprache sowie der üblichsten Gauner-, Matrosen-, Sport- und Zunft-Ausdrücke; mit Einleitung und Musterstücken / Ein Supplement zu allen englisch-deutschen Wörterbüchern. "Zweite verbesserte und stark vermehrte Auflage". Berlin-Schöneberg: Langenscheidtsche Verlagsbuchhandlung (Prof. G. Langenscheidt).

Beardsmore, Hugo Baetens (1967): "Quelques considérations sur le 'Dictionnaire du dialecte bruxellois' de M. Louis Quiévreux". Revue des Langues Vivantes / Tijdschrift voor Levende Talen 33, 3: 309-322.

Blanc, Haim (1954): "The Growth of Israeli Hebrew". Middle Eastern Affairs 5: 385-392 [rev. Gold 1983c].

Brook, G[eorge] L[eslie] (1970): The Language of Dickens. London: André Deutsch.

Brown, Ivor (1962): Mind Your Language! London: The Bodley Head.

Brown, William (1814): The History of the Propagation of Christianity among the Heathen before the Reformation. 2 vols. London: Longman, Hurst, Rees, Orme \& Brown. Edinburgh: "Printed for D. Brown".

Bruni, Frank (2007): “Critic's Notebook: When Accessibility Isn't Hospitality”. The New York Times, 12 September. Pp. F1 and F10.

B[urchfield], R[obert] W. (1986): "Preface". In OEDS, vol. IV, pp. vii-xiii.

$C D C=$ The Century Dictionary and Cyclopedia: An Encyclopedic Lexicon of the English Language and a Pronouncing and Etymological Dictionary of Names in Geography, Biography, Mythology, History, Art, etc. together with atlas of the world (1895): Revised 
edition. "Prepared under the superintendence of William Dwight Whitney" [he died on 7 June 1894]. New York: The Century Co.

Chambers, Raymond W., and Marjorie Daunt, eds. (1931): A Book of London English, 1384-1425. Oxford: At the Clarendon Press [unseen].

Chapman, R[obert] W[illiam] (1920): The Portrait of a Scholar and Other Essays Written in Macedonia / 1916-1918. London: H. Milford / Oxford University Press [reprint, Freeport, New York: Books for Libraries Press, 1968].

Chapman, Robert L. (1986): New Dictionary of American Slang. New York: Harper \& Row [rev. Gold 1990a].

Clarke, Marcus (1874): [untitled]. Notes and Queries. A Medium of Intercommunication for Literary Men, General Readers, Etc. Fifth series. Vol. II. 12 December. P. 478.

Courtney, M[argaret] A., and Thomas Q. Couch (1880): A Glossary of Words in Use in Cornwall. West Cornwall, by Miss M. A. Courtney. East Cornwall by Thomas Q. Couch. English Dialect Society [unseen].

Crystal, David (1995): The Cambridge Encyclopedia of the English Language. Cambridge, England: Cambridge University Press [rev. Gold ms. 2].

Darnton, John (1996): "London Journal: England's Toffs and Yobs: Sports Draws the Line". The New York Times. 27 June. P. A4.

DeCaro, Frank (1999): "Style Over Substance: Clothing Optional Beyond This Point". The New York Times. 29 August. "Styles" section. P. 6.

de Tollenaere, F[élicien] (1983): "Woord vooraf". In de Vries 1983: 27-30.

de Vries, J. (1983): Etymologisch woordenboek. "Geheel opnieuw beweerkt door dr. F. de Tollenaere". Thirteenth edition. Utrecht and Antwerp. Uitgeverij Het Spectrum.

Dickens, Charles (1853): "Slang". Household Words. Vol. VIII. Whole no. 183. 24 September. Pp. 73-78.

Dobson, E[ric] J[ohn] (1968): English Pronunciation 1600-1700. Second edition. 2 vols. Oxford: At the Clarendon Press.

Elmes, James. 1831. A Topographical Dictionary of London and Its Environs, Containing Descriptive and Critical Accounts of All the Public and Private Buildings, Offices, Docks, Squares, Streets, Lanes, Wards, Liberties, Charitable Institutions, Scholastic and Other Establishments, With Lists of Their Officers, Patrons, Incumbents of Livings, \&c. \&c. \&c. in the British Metropolis. London: Whittaker, Treacher \& Arnot.

Farmer, John S[tephen], and W[illiam] E[rnest] Henley (1890-1904): Slang and Its Analogues, Past and Present. A Dictionary, Historical and Comparative, of the Heterodox Speech of all Classes of Society for More than Three Hundred Years. With Synonyms in English, French, German, Italian, etc. 7 vols. [London, Edinburgh]: "Printed for Subscribers Only" [facsimile reprint, Slang and Its Analogues, with an introduction by Theodore M. Bernstein, New York, Arno Press, 1970; reference to "Henley and Farmer," occasionally heard or seen, is a slip of the tongue or pen].

(1903-1909): Dictionary of Slang and Its Analogues Past and Present. 2 vols. [= revised and enlarged edition of the letters $A$ and $B$ in Farmer and Henley 1890-1904; reprint, with introductions by Lee Revens and G. Legman, New Hyde Park, New York, University Books, 1966; unseen; we need to determine whether the authors changed any part of their earlier treatment of the words under scrutiny in the present article].

Feinsilver, Lillian Mermin (1970): The Taste of Yiddish. South Brunswick, New York, and London: Thomas Yoseloff. 
Ferguson, John Alexander (1941-1986): Bibliography of Australia. 7 vols. Sydney: Angus and Robertson [in the addenda section of volume 4, the broadside is described in entry 1390a, which was repeated as entry 1390aaaa on page 219 of the revised edition of volume 1 that appeared in 1986].

Franklyn, Julian (1953): The Cockney: A Survey of London Life and Language. Revised edition. London: André Deutsch [the revised edition appeared in May; the first edition had appeared in February of the same year].

Franz, W. (1889): "Die Dialektsprache bei Ch. Dickens". Englische Studien XII: 197-244 [unseen].

Gelber, Mark (1979): “Teaching 'Literary Anti-Semitism': Dickens' Oliver Twist and Freytag's Soll und Haben". Comparative Literature Studies. Vol. 16. No. 1. March. Pp. 1-11 [rev. Gold 1981a].

Gerson, Stanley (1967): Sound and Symbol in the Dialogue of the Works of Charles Dickens: A survey of the divergencies from normally received spellings in the dialogue of Dickens's works, together with an investigation into Dickens's methods of conveying an impression of divergent sounds of speech. Stockholm, Göteborg, and Malmö: Almqvist \& Wiksell.

Glossary of British Argot [a 12-page pamphlet issued by Paramount Pictures to help the American (and Canadian?) public understand the dialog in its films with London locales; unseen].

Gold, David L. (1981a): Review of Gelber 1979. Jewish Language Review 1: 143-145.

(1981b): Review of Steinmetz 1976. Jewish Language Review 1: 158 [additions in vol. 2, 1982, pp. 318-319, vol. 3, 1983, p. 417, vol. 4, 1984, p. 420, vol. 6, 1986, pp. 303-304, vol. 7, 1987, p. 614, and Jewish linguistic Studies, vol. 2, 1990, p. 507].

(1982a): Etymological Studies of Jewish Interest, Part I [= Comments on Etymology, vol. XI, no. 15,1982$]$.

(1982b): Review of Beardsmore 1967. Jewish Language Review 2: 102-103.

(1982c): "More on Yiddish shmok". Comments on Etymology 11, 15: 33-37.

(1983a): "From Latinic *purgare to British Jewish English porge: A Study in Jewish Intralinguistics". Jewish Language Review 3: 117-155 [additions and corrections in vol. 4, 1984, p. 422, vol. 6, 1986, p. 395, and Jewish Linguistic Studies, vol. 2, 1990, p. 517; Jewish Latin has now replaced the glottonym "Latinic"].

(1983b): "Recent Yiddish Studies from Israel, Germany, the United States, the Netherlands, Switzerland, and Canada (Review-Essay.)" Jewish Language Review 3: 157-179. (1983c): Review of Blanc 1954. Jewish Language Review 3: 204-207 [additions and corrections in vol. 7, 1987, p. 615].

(1983d): "More on Yiddish shmok: Part 2". Comments on Etymology 12, 11-12: 38-66.

(1984a): "The Etymology of the English Bread Name pita (A Study in Jewish Intralinguistics)". Jewish Language Review 4: 58-76.

(1984b): "Gentlemen, We Know More Yiddish Than We Admit (On Werner Weinberg's

Die Reste des Jüdischdeutschen)". Jewish Language Review 4: 77-123 [additions and corrections in vol. 5, 1985, pp. 454-455, vol. 6, 1986, pp. 400-401, vol. 7, 1987, p. 616, and Jewish Linguistic Studies vol. 2, 1990, pp. 518-519].

(1985a): "A Guide to the Standardized Yiddish Romanization. Jewish Language Review

5: 96-103 [additions and corrections in vol. 6, 1986, pp. 407-408].

(1985b): Review of Holt 1961. Jewish Language Review 5: 225-232.

(1985c): Review of Stern 1985. Jewish Language Review 5: 334-338. 
(1986a): “An Introduction to Jewish English". Jewish Language Review 6: 94-120 [additions and corrections in vol. 7, 1987, p. 622, and Jewish Linguistic Studies, vol. 2, 1990, pp. 525-527].

(1986b): "Jewish English sit shive (On the Continuum Between Jewish English and General English); With Supplements on yortsayt calendar and Relevant Terms in Judezmo". Jewish Language Review 6: 137-143 [additions and corrections in vol. 7, 1987, pp. 623-624, and Jewish Linguistic Studies, vol. 2, 1990, pp. 527-528].

_ (1989a): Jewish Linguistic Studies [vol. 1]. Haifa: Association for the Study of Jewish Languages.

— (1989b): "On the Supposed Yiddish Origin of the English Noun gazump (With an Appendix on Other English Words of Yiddish or Supposed Yiddish Origin". In Gold 1989a: 26-34 [the word, which has no Jewish connection, linguistic or otherwise, consists of English [the price] goes up and non-etymological $/ \mathrm{m} /$ ].

- (1989c): "More on the Origins of the English Bread Name pita (With a Supplement on Hungarian Influence on Hebrew)". In Gold 1989a: 42-52 [incorporating, with corrections, and thus superseding, the author's "Another Look at Israeli Hebrew pita 'flat bread': A Borrowing from Judezmo and Yiddish," Romance Philology, vol. 42, no. 3, February 1989, pp. 276-278]. , ed. (1990a): Jewish Linguistic Studies. Vol. 2. Haifa: "Copyright by the Editor".

- (1990b): "Fiction or Medieval Philology (on Isaac E. Mozeson's The Word: The Dictionary That Reveals the Hebrew Source of English)". In Gold 1990a: 105-133.

$134-158$.

_ (1990d): "On the Etymology of the English Coin Name caser "crown"”. In Gold 1990a: $159-168$.

(1990e): "More on English ganef and Other Words". In Gold 1990b: 192-197.

(1992): [letter to the editor]. Verbatim: The Language Quarterly XVIII, 4: 15-16.

(1995): "When Religion Intrudes into Etymology (On The Word: The Dictionary That Reveals The Hebrew Source of English)". In Kachru and Kahane 1995: 369-380.

(2001): "For the Umpteenth Time: The Non-Jewish Dutch-Origin Family Name Roosevelt Has No German or Jewish Connection". Beiträge zur Namenforschung. [New Series] 36, 1: $37-38$.

(2005a): "Dickens, 'Theatricals' and Oxford English Dictionary: A Correction". The Dickensian. Vol. 101. Part 3. Whole no. 467. Winter. Pp. 240-241.

- (2009a): Studies in Etymology and Etiology (With Emphasis on Germanic, Jewish, Romance, and Slavic Languages). Selected and edited, with a foreword, by Félix Rodríguez González and Antonio Lillo Buades. Alicante: Publicaciones de la Universidad de Alicante.

(2009b): "Towards a Dossier on the Still Unclear Immediate Etymon(s?) of American English Slang hooker 'whore' (With Remarks on the Origin of American English Barnegat, Dixie, fly vlei vley vlaie vly, Gramercy Park, Hell Gate, jazz, sloughter, and Spuyten Duyvil)". In Gold 2009a: 105-162.

(2009c): "Nine Criteria for Assessing the Likelihood of Yiddish Influence on English (With Examples)". In Gold 2009a: 237-255.

(2009d): "When Chauvinism Interferes in Etymological Research: A Few Observations on the Supposed Vulgar Latin Derivation of Rumanian pastramă păstramă, a Noun of Immediate Turkish Origin (With Preliminary Remarks on Related Words in Albanian, Arabic, Armenian, English, French, Greek, Hebrew, Judezmo, Polish, Russian, SerboCroatian, Spanish, Turkish, Ukrainian, and Yiddish)". In Gold 2009a: 271-375. 
- (2009e): “Who Can Decipher (Yiddish?) *‘bashtem’ and (Yiddish?) *‘ghop bagi’?” In Gold 2009a: 571-581.

- (2009f): "Jewish Dickensiana, Part One: Despite Popular Belief, the Name Fagin in Charles Dickens's Oliver Twist Has No Jewish Connection (With Appendixes on Some Laws Concerning Personal Names and on Dickens's Authentic Yiddish Name)". In Gold 2009a: 723-857.

- ms. 1. "A Hitherto Unrecognized Family of Words Going Back In One Way or Another to Hebrew chaver: Australian English cobber, European Dutch gabber, German Chawer, etc., Jewish Italian xaver, Judezmo xaver, New Zealand English cobber, Rotwelsch Cabber Kabber, San gaba, South African English chabba gabba gubba, Spanish háber, and Yiddish khaver".

ms. 2. "One Hundred and Thirty-Four Comments on David Crystal's The Cambridge Encyclopedia of the English Language".

ms. 3. "An Examination of Six of the Entries of Jewish Interest in the 1902 edition of Heinrich Baumann's Londonismen (Slang and Cant) Wörterbuch der Londoner Volkssprache sowie der üblichsten Gauner-, Matrosen-, Sport- und Zunft-Ausdrücke / Mit Einleitung und Musterstücken / Ein Supplement zu allen englisch-deutschen Wörterbuchern".

ms. 4. "Jewish Dickensiana, Part Two: Almost All the 'Jewish' Features of the Speech of Charles Dickens's Jewish Characters Are Unauthentic".

_ in prep. 1. "Eric Partridge: Avid Collector, Bad Etymologist".

- in prep. 2. "Were the Counties of Kings and Queens (now in New York State) Named Respectively for All the Kings and All the Queens of Great Britain and Ireland or Just for Charles II and Catherine of Braganza? (On the Difficulty of Interpreting English Texts Written Before the Introduction of an Apostrophe to Indicate the Possessive Forms of Nouns)".

in prep. 3. "The First Serious Treatment of the English Ethnophaulisms kike 'Jew' and sheeny "idem".

— in prep. 4. "The Influence of Yiddish on Polish Seen from the Yiddish Side".

Gosling, John (1959): The Ghost Squad. London: W. H. Allen.

Grimes, William (2009): “Christopher Hibbert, 84, Lively Historian”. The New York Times. 9 January. P. A18.

Grünewald, K. (1914): Die Verwendung der Mundart in den Romanen von Dickens, Thackeray, Eliot und Kingsley. University of Darmstadt dissertation [unseen].

Haberman, Clyde (2011): "For Japanese, Learning To Receive". The New York Times. 15 March. P. A26.

Harkavy, Alexander (1925): Yiddish-English-Hebrew Dictionary. New York: "Published by the author".

- (1928): Yiddish-English-Hebrew Dictionary. New York: Hebrew Publishing Company.

Herzog, Marvin I[rving] (1965): The Yiddish Language in Northern Poland: Its Geography and History. Bloomington: Indiana University Press.

Hibbert, Christopher (1967): The Making of Charles Dickens. London: Longmans, Green \& Co. [reprints, London, Penguin Books, 1967; New York and Evanston, Harper \& Row, Publishers, 1967; London, Penguin Books, 1983; and London, Classic Penguin, 2000].

Höfer, G. (1896): Die Londoner Vulgärsprache. University of Marburg dissertation [unseen]. Holder, R.W. (2004): The Dictionary Men: Their Lives and Times. Bath: Bath University Press.

Holt, Alfred H. (1961): Phrase and Word Origins: A Study of Familiar Expressions. New York: Dover. 
Homerin, Th. Emil (2003): [Excerpt from an address on the occasion of the initiation of newly elected members into the Phi Beta Kappa Society]. The Key Reporter 68, 3: 6-7.

[Hotten, John Camden] (1873): The Slang Dictionary, Etymological, Historical, and Anecdotal. London: Chatto \& Windus.

House, Humphrey (1942): The Dickens World. London, New York, and Toronto: Geoffrey Cumberlege / Oxford University Press.

Jagger, J[ohn] Hubert (1940): English in the Future. London. Thomas Nelson and Sons Ltd.

Kachru, Braj B., and Henry Kahane, eds. (1995): Cultures, Ideologies, and the Dictionary: Studies in Honor of Ladislav Zgusta [= Lexicographica: Series Maior, vol. 64]. Tübingen: Max Niemeyer Verlag.

Korach, Myron, in collaboration with John B. Murdock (2008): Common Phrases and Where They Come From. Second edition. New York. Lyons Press $\left(2002^{1}\right)$.

Lee, Jennifer 8 (2009): “Could 9/9/09 Be a Special Day?” The New York Times. 5 September. P. A15.

Liberman, Anatoly (2010): "Oxford Etymologist: Unable to Put the Kibosh on a Hard Word". Internet posting, 19 May [a supplement was posted on 28 July 2010].

Lieberman, Saul, ed. (1950): Alexandar Marx Jubilee Volume on the Occasion of His Seventieth Birthday. New York: The Jewish Theological Seminary of America. 2 vols.

Lillo, Antonio (2000): "Bees, Nelsons, and Sterling Denominations: A Brief Look at Cockney Slang and Coinage". Journal of English Linguistics 28, 2: 145-172.

Loewe, H[erbert] (1924): “'Kaibosh,' 'To put the Kaibosh on." Notes and Queries: For Readers and Writers, Collectors and Librarians 147, 14: 244-245.

MacBride, MacKenzie (1910): London's Dialect: An Ancient Form of English Speech: With a Note on the Dialects of The North of England and the Midlands and of Scotland. London: The Priory Press [unseen].

Mackenzie, Barbara Alida (1928): The Early London Dialect: Contributions to the History of the Dialect of London During the Middle English Period. Oxford: At the Clarendon Press [reprints, [Folcroft, Pennsylvania], Folcroft Library Editions, 1974; Norwood, Pennsylvania, Norwood Editions, 1976; Philadelphia, R. West, 1977; all unseen].

Malkiel, Yakov (1968): Essays on Linguistic Themes. Berkeley and Los Angeles: University of California Press.

Marcus, Jacob Rader (1950): "A Brief Supplement to the Standard Hebrew Dictionaries of Abbreviations". In Lieberman 1950, English section, pp. 447-480.

Matthews, William (1938): Cockney Past and Present: A Short History of the London Dialect. London: Routledge; New York: E.P. Dutton \& Company [the imprint published by George Routledge \& Sons, Ltd. (London, 1938) is called Cockney Past and Present: A Short History of the Dialect of London].

McCall, Bruce (1997): "Shouts \& Murmurs: A Glimpse Back from 2050". The New Yorker. 20 and 27 October. P. 270.

MDIY = The Monumental Dictionary of Imaginary Yiddish. 100 vols. The World Academy of Yiddishless Yiddish "Experts". In preparation.

Merriam-Webster's Dictionary of English Usage (1994): Springfield, Massachusetts: MerriamWebster, Publishers, Incorporated.

Mihm, Stephen (1999): "Milestones, Millstones As Design Marches On”. The New York Times. 30 December. Pp. F1 and F6-F7.

Montague, C.E. (1930): A Writer's Notes on His Trade. London: Chatto and Windus [reprint, Port Washington, New York, Kennikat Press, 1969]. 
[Montefiore, Judith] (1846): The Jewish Manual, or, Practical Information on Jewish \& Modern Cookery, With a Collection of Valuable Recipes \& Hints Relating to the Toilette / edited by a lady. London. T. \& W. Boone [the consensus is that Judith Montefiore (1784-1862), the wife of Moses Montefiore, wrote this anonymous book; its Jewish terminology needs to be analyzed; two facsimile reprints appeared in 1983: one under its original title (New York, NightinGale Books, with an introduction by Chaim Raphael) and one as Lady Montefiore's Cookbook: With Illustrations and Foreword by Mark Negin: The First Jewish Cookbook in English, Edited Anonymously and Published in 1846 ([Ramsgate, Kent], Michaels Bookshop)].

Morell, Virginia (2001): "Pyramid Builders". National Geographic 200, 5: 78-99.

Morris, William and Mary (1985): Harper Dictionary of Contemporary Usage. Second edition. New York: Harper \& Row, Publishers.

Muschamp, Herbert (2000): "Museum Unveils Libeskind's Design". The New York Times. 23 February. Pp. E1 and E8.

$N E B=$ The New Encyclopadia Britannica (1991): Fifteenth edition. Chicago: Encyclopædia Britannica, Inc.

Nelson, Harland S. (1981): Charles Dickens. Boston: Twayne Publishers.

Newman, Robin Gorman (2006): How to Marry a Mensch: The Love Coach's Guide to Meeting Your Mate. Gloucester, Massachusetts: Fair Winds Press.

NID2 = Webster's New International Dictionary of the English Language: Second Edition: Unabridged (1934): William Allan Nelson, editor in chief. Springfield, Massachusetts: G. \& C. Merriam Company, Publishers [addenda sections appeared in 1939, 1945, 1950, and 1954].

NID3 = Webster's Third New International Dictionary of the English Language: Unabridged (1961): Philip Babcock Gove, editor in chief. Springfield, Massachusetts. Merriam-Webster, Inc., Publishers [addenda sections appeared in 1966, 1971, 1976 (also published separately, as 6,000 Words), 1981 (also published separately, as 9,000 Words), 1986 (also published separately, as 12,000 Words), 1993 (also offprinted), and 2002; silent corrections have also been made from time to time].

19th Century UK Periodicals. Gale Cengage Learning.

Nisbet, Ada B[lanche] (1964): “Charles Dickens”. In Stevenson 1964: 44-153.

O'Connor, J.D. (1948): New Phonetic Readings from Modern English Literature. Berne: A. Francke AG, Verlag.

OED = The Oxford English Dictionary $\left(1933^{1}\right)$ : Oxford: Oxford University Press. [first published as A New English Dictionary on Historical Principles]. $1989^{2}$ [the second edition seems to be just a conflation of the first one and $O E D S]$.

OEDS = A Supplement to The Oxford English Dictionary (1972-1986): 4 vols. R[obert] W. Burchfield, editor. Oxford: At the Clarendon Press.

Owen, Trefor (2010): [Posting]. "The Crispin Colloquy Open Forum: archive 76/100. Techniques, Crans and Visualizations: Glues and Cements: archive 76-100". 14 August. www.thehcc.org/discus/messages/4/12684.html?1296336289 [accessed on 7 February 2012].

Parker, George (1800): Life's Painter, Variegated Characters in Public and Private Life, With Political Strokes on the Ticklish Times [...]. London: J. Ridgway.

Partridge, Eric (1984): A Dictionary of Slang and Unconventional English / Colloquialisms and Catch Phrases / Solecisms and Catachreses / Nicknames and Vulgarisms. Eighth edition. Paul Beale, ed. New York: Macmillan Publishing Company. 
(1989): A Concise Dictionary of Slang and Unconventional English. Paul Beale, ed. New York: Macmillan Publishing Company.

Phillipps, K.C. (1984): Language and Class in Victorian England. Oxford: Basil Blackwell in association with André Deutsch.

Phillips, George L. (1951): "The Crispin Colloquy Open Forum: archive 76/100. Kibosh on Mencken's 'kibosh.” Modern Language Notes LXVI: 330-331.

Platt, Jun., Jas. (1896): "Slang and Its Analogues". Notes and Queries: A Medium of Communication for Literary Men, General Readers, Etc. Eighth series. Vol. XCIII. No. 227. 2 May. P. 345.

Platt, William ([1910]): James Platt the Younger: A Study in the Personality of a Great Scholar. London: Simkin Marshall \& Co.

Potter, Simeon (1961): Our Language. Harmondsworth, Middlesex: Penguin Books [a reprint with a revised bibliography].

Quirk, Randolph (1959): Charles Dickens and Appropriate Language: Inaugural Lecture of the Professor of English Language delivered in the Applebey Lecture Theatre on 26 May 1959. Durham: University of Durham.

- (1961): "Some Observations on the Language of Dickens". Review of English Literature. July. Pp. 19-28 [unseen].

Reynolds, G[eorge] W[illiam] M[acArthur] (1845-1856): The Mysteries of London. London. J. Dicks [series 1, 1845-1846; series 2, 1847-1848; series 3, 1853-1854; and series 4, 1856].

RH $=$ The Random House Dictionary of the English Language: Second Edition: Unabridged (1987): Stuart Berg Flexner, editor in chief. New York: Random House, Inc.

Rivkind, Yitskhok (1959): Yidishe gelt. New York: American Academy for Jewish Research.

Safire, William (1980): On Language. New York: Times Books.

Schuchardt, Hugo (1909): "Die Lingua Franca". Zeitschrift für romanische Philologie 33: 444 461.

Sivertsen, Eva (1960): Cockney Phonology. Oslo: Oslo University Press. New York: Humanities Press [= Oslo Studies in English, No 8; Publications of the British Institute in the University of Oslo].

Steinmetz, Sol (1976): "The Bottom line on the bottom line". American Speech: A Quarterly of Linguistic Usage 51, 1-2: 56.

Stern, Heidi (2000): Wörterbuch zum jiddischen Lehnwortschatz in den deutschen Dialekten [= Lexicographica: Series Maior, vol. 102]. Tübingen: Max Niemeyer Verlag.

Stern, Josef (1985): “Jüdisch-Deutsch". MB: Wochenzeitung des Irgun Olej Merkas Europa. Vol. 53. No. 6. 8 February. Pp. 7 and 8.

Stevenson, Lionel, ed. (1964): Victorian Fiction: A Guide to Research. Cambridge, Massachusetts: Harvard University Press [reprint, Cambridge, Massachusetts, Harvard University Press, 1966].

Swenson, Alfred, and Pao-Chi Chang (1991): "Building Construction". NEB 15: 312-339. (1907): "How Dickens Corrected His Proofs". The Dickensian 3, 11: 297-298. 2011].

unsigned (1911): "kurbash". The Encyclopaedia Britannica: A Dictionary of Arts, Sciences, Literature and General Information. Eleventh edition. Cambridge and New York: At the University Press. Vol. XV. P. 949.

unsigned (1956): "Bagel Strike Threat Off; 250 Bakers in City Get a \$6 Rise, and Their Helpers, \$5". The New York Times. 4 February. P. 40. 
Urdang, Laurence (1988): The Whole Ball of Wax and Other Colloquial Phrases: What They Mean \& How They Started. New York: Perigee Books / The Putnam Publishing Group.

Vallins. G.H. (1960): The Best English. London: André Deutsch.

Vaynraykh, Maks (1957-1958): "Bney-hes un bney-khes in ashkenez: di problem — un vos zi lozt undz hern”. Yivo-bleter XLI: 101-123.

Voorzanger, J[onas van] L[evie], and J[ohn] E[vert] Polak (1915): Het Joodsch in Nederland: aan het Hebreeuwsch en andere Talen ontleende Woorden en Zegswijzen, verzameld en toegelicht. Amsterdam: N.V. de erven H. van Munster.

Ward, Ida C. (1929): The Phonetics of English. New York: D. Appleton and Company.

Webster's New World Dictionary of the American Language (1953): [First] College Edition. Joseph H. Friend and David B. Guralnik, general editors. Cleveland and New York: The World Publishing Company.

Weekley, Ernest (1930a): Adjectives — and Other Words. London: John Murray. New York: E.P. Dutton and Company, Inc. [reprint, Freeport, New York, Books for Libraries Press, 1970].

- (1930b): “Mrs. Gamp and the King's English". In Weekley 1930a: 138-161.

Wentworth, Harold, and Stuart Berg Flexner (1975): Dictionary of American Slang. New York: Thomas Y. Crowell Company. Second supplemented edition.

Wescott, Roger (1979): "Lexical Polygenesis: Words as Resultants of Multiple Linguistic Pressures". The Fifth LACUS Forum, 1978. Pp. 81-92.

Westendorpf, Karl (1923): Das Prinzip der Verwendung des Slang bei Dickens. Greifswald: Adler [unseen].

Wright, Joseph (1898-1905): The English Dialect Dictionary, Being The Complete Vocabulary of all Dialect Words still in use, known to have been in use during the last Two Hundred Years, founded mainly on the Publications of the English Dialect Society and on a large amount of material never before printed. 6 vols. Oxford, London, Edinburgh, New York, and Toronto: Henry Frowde [reprint, London, Oxford University Press, 1970].

Wyld, Henry Cecil (1936): A History of Modern Colloquial English. Third edition. Oxford. Basil Blackwell $\left[1920^{1}, 1921^{2}\right]$.

Zimmer, Amy (2009): "City: No way private security is going in Wash. Square Park". Metro. New York. 23 June. P. 4. 